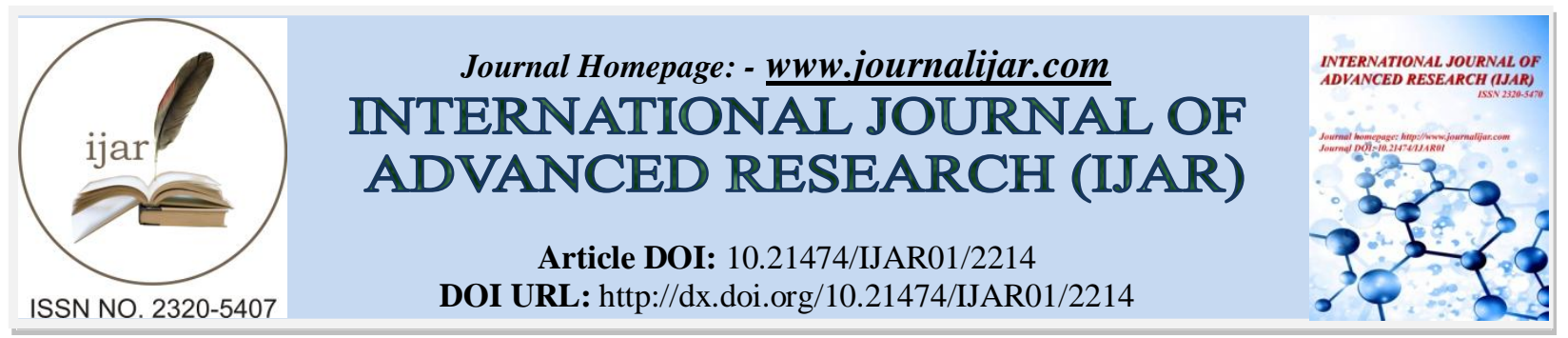

RESEARCH ARTICLE

\title{
REPRESENTATION OF INDIVIDUAL WILL AS THE AGENT OF SOCIAL TRANSFORMATION IN WOLE SOYINKA'S NOVELS.
}

Ouno Victor Onyango ${ }^{1}$, Prof. Arthur Luvai ${ }^{1}$ and Prof. Oluoch Obura ${ }^{2}$.

1. Department of Literary Studies, Maseno University.

2. Department of Literature, Kenyatta University.

\section{Manuscript Info}

Manuscript History

Received: 28 September 2016

Final Accepted: 30 October 2016

Published: November 2016

\section{Abstract}

This study focuses on representation of individual will as the vehicle of social transformation in Wole Soyinka's novels. The Interpreters and Season of Anomy constitute the study population and the main sources of primary data for this study. The primacy of individual will in social transformation is an integral philosophy in Soyinka's literary writings. Viewing social reconstruction as a recurrent process; the study employs dialectical materialism, a brand of Marxism, which forms a vantage theoretical prism. This study demonstrates that the two novels represent Soyinka's fictionalisation of attempts to realign social constructs and the strength of individual characters reigns in this quest. Soyinka invests enormous artistic energy in the lone, individual character and he bequeaths this loner the exclusive preserve of galvanising society and steering it towards reconstruction. The communal aspirations and energies for the revolutionary transformation of the patterns of social and cultural production are bestowed on the larger-than-life hero.

Copy Right, IJAR, 2016,. All rights reserved.

\section{Introduction:-}

Soyinka's works have attracted a lot of attention. While it may be difficult to delineate the fine details of the sociopolitical and economic lineaments inherent in Soyinka's literary works, there is need for critics to conduct studies that constitute a more crystallizing platform in the determination of his ideological intentions which are thinly disguised in his creative sensibility. It is, in this regard, not possible to say that adequate research has been conducted on his creative writings. In particular, Soyinka's inclination towards individual will as the agent for social transformation has not been sufficiently dealt with in the critical materials that are in existence. In cases where subtle references have been made, the evidence adduced from the selected novels is not sufficient. Such lack of adequate evidential materials reduces most of the commentaries high lighted in the critical studies to sweeping statements. There are very significant critical gaps that emerge from the criticisms. This paper attempts to seal these gaps by subjecting the two novels, The Interpreters and Season of Anomy, to further investigation to ascertain the extent to which they subscribe to the contention that Soyinka's works reify promethean individualism. To this end, this paper intends to justify the centrality of individual will as the most credible vehicle of social transformation. The opposing philosophies that are explored in Soyinka's works are individualism and collectivism. This section seeks to demonstrate that there is a deliberate effort to elevate the individual will as the vehicle of social transformation. One of the consequences of Soyinka's increasing dedication to the cause of justice is that the world 
of his post-war imaginative writings is frequently dominated by visionary seekers. One encounters these pilgrims early in some poems in A Shuttle in the Crypt.

One of the critics that have weighed in on this debate is Msiska Mpalive-Hangson investigates Soyinka's representation of treatment of the relationship between individual selfhood and loosely observes that the various framing of social and collective identities is yet another aspect linking Soyinka's works to the broader intellectual currents of today. Another scholar, Balogun, defends Soyinka against what other writers consider as lack of commitment to Marxist ideals and the attendant socialist implications. He cautions against hasty dismissal of Soyinka's literary works on account of a superficial non-committal attachment. He bemoans ' $[t]$ he frequency and eagerness with which he is attacked by the masochistic mindlessness involved in the act of throwing the baby with the bath water.' He observes:

The litany of Soyinka's Marxist sins is staggering: His is a feudalist mentality upholding a hegemonic, reactionary view of African history ... he is a bourgeois intellectual whose social analysis is uninformed by scientific materialist dialectics; he is a cynic peddling pessimistic philosophy of human history, a chronic individualist that sees periodic salvation in man's history of cyclic futility only in terms of the heroic acts of lonely messianic individuals ... (513)

Balogun reflects critics' rejection of Soyinka's commitment to materialist dialectics and acknowledge that the individual is central to Soyinka's depiction of redemption. His sentiments are shared by Chidi, who overstretches Marxism and contends that the solution to this theoretical futility is best provided in Chidi Amuta's The Theory of African Literature where he opines that 'the way out seems to lie in a recourse to the philosophical breakthrough which Marxism represents, namely, historical materialism' which 'transcends Marxism and embodies a certain general theoretical elasticity that could save Marxism from its present crisis and imminent obsolescence.' Indeed, Katrak Ketu's 'Theory and Social Responsibility: Soyinka's Essays,' wittingly observes that society attaches great sense of value to members' freedom from oppressive leadership and recognizes Soyinka's preference for individuality. Society values cultural identity as an instrument of self-determination. Members are valued for their individual commitment and contribution to the general welfare of the society (500).

Lawrence Ogbo Ugwuanyi, in 'I am Therefore You Are: An Existentialist Perspective on Wole Soyinka's Writings,' identifies as an African 'version or equivalent of Fredrick Nietzsche in the sense that both writers perceive the strength of a character as the only way out of the cynicism that characterises human life. His journal critiques Soyinka's works against the existentialist theory. His work is, therefore, relevant to this study as it appreciates Soyinka's deep attachment to centrality of individual will. It, however, focuses on the pessimism that defines human life. He says:

In the first place the two thinkers define life and meaning in terms of the will to action. Similarly, the two thinkers believe that the ontological pessimism that defines life should be subverted through sheer force of the will. The will in question is not one that leads to a religious or supernatural ethics but a natural belief that man can as well invent a meaning for life. Thus while a certain kind of ontological pessimism runs through Soyinka's works for which birth and death are portrayed as the same route to nothingness, there is the persisting belief in him that the individual will can surmount the sickening pessimism that defines life. The route to this then lies in the will to action (81).

Aisha Karim's article, 'Crisis of Representation in Wole Soyinka's Season of Anomy', argues that Soyinka's novel Season of Anomy marks a departure from any commitment as such that opens the text to new political possibilities. Aisha further contends that while Season of Anomy presents us with an alternative to the politics and poetics that define Soyinka's dramatic output, it does so only to the extent that it imagines itself as a 'failed text.' Aisha's argument is that what emerges as a crisis of representation within the text consequently allows the reader to recognise herself as the agent of change on the level of the social. In this study, she distances herself from Soyinka's commitment to individual will. The study that the researcher seeks to undertake here departs from this argument and instead proves that Season of Anomy, like The Interpreters and other literary texts that are explicitly or implicitly alluded to, reinforce the centrality of this philosophy in Soyinka's works. The study will demonstrate that the initiative to transform the society emanates from individuals. It focuses on how individual characters in the two selected novels consciously make efforts to transform the society. 
The Portraiture of Individual Will as the Agent of Social Transformation in Soyinka's Novels:-

A good understanding of the treatment of the two philosophies in the two texts selected calls for a brief summary of Nigeria's socio-political history, especially the periods that are represented in the texts in question. Soyinka's role in the construction of this history is equally important in the comprehension of his fictionalised representation. This does not, however, imply that the representations in the texts are strictly applicable to the Nigerian context; indeed, Nigeria will merely serve as a microcosm of the wider post-independent African society. There are strong indications of shared experiences in the depiction of the post-independent Nigeria.

The Interpreters is published five years after the attainment of self-rule in Nigeria and Season of Anomy comes out nearly eight years later. Before the declaration of independence, the natives were in constant conflict with the British colonialists over intrusion. The celebration of liberation from the shackles of the colonizer marked the realisation of a synthesis that then formed the thesis of the new triad. The celebration of independence, however, was short-lived. The Nigerian society, like most post-independent African nations, slid back to slavery. The only difference, which was in any case the same, to put it oxymoronically, was the change of the master. Colonialism was supplanted with neo-colonialism. The Interpreters reflects the period immediately after independence and, in this sense, it captures the disillusionment that characterised the newly independent country, particularly the country's degeneration into a new form of subjugation. Season of Anomy, Soyinka's second novel, is a perfection of this degeneration. It reflects the resistance to the new form of slavery. Perhaps Palmer's observations capture this period more succinctly:

To many, it seemed that the continent was retrogressing to a state of barbarism where the ordinary human being was deprived of all rights and his life was of no account to the authorities ...The immediate post-independence phase of social and political corruption and intellectual dishonesty was now giving way to a bleaker phase of dictatorship, victimization, thuggery and violence organised occasionally at the highest level, and a prevailing atmosphere of fear (267-68)

The publication of Season of Anomy follows two successive coup d'états that led to the massive loss of human lives in Nigeria. It is the second coup that culminated in civilian protests and violence in so many parts of the country. Undeniably, the Igbos suffered great casualties; thousands of them were brutally murdered in Northern Nigeria. The civilian protests and violence were believed to have been brought about by the revulsion against the socio-political and economic gains that had been realised by the Igbos shortly after the declaration of the country's self-rule. The new breed of political elites and drivers of the country's economy were mainly drawn from this community. Other dominant tribal groupings, like the Yoruba, felt discriminated against and viciously attacked them with a view to putting an end to this economic and political dominance.

The unfolding of these series of violence was an issue of deep concern for Soyinka. It disturbed Soyinka that two factions of his society were at loggerheads over physical appetites for material gain. Out of his regard for moral obligations, he played his role as a good citizen, an ambassador of peace. Despite the fact that he himself hailed from Yoruba, Soyinka toured the affected regions in order to reconcile the Federal Military Government and the rebellious Biafran forces. In one of his tours of the regions, the rebels set on him and he only escaped death by a whisker. His initiatives were, however, misconstrued; a number of forces from Igbo faction perceived his efforts as attempts to promote the interests of the Yoruba.

But these experiences are not exceptional to Soyinka. Recently, when Achebe, who had shunned the topic throughout his literary career, wrote an autobiographical text, There was a Country, which delves into the Biafran war; the media were awash with negative criticisms of Achebe's account. Of great concern were attempts, considered deliberate by the Yoruba, to vilify and indeed pour profane vitriol on Awolowo who had been accorded a deified stature in the community. Soyinka himself celebrates the heroic stature of this figure in one of poems in Idanre and Other Poems, 'In Memory of Segun Awolowo' (Idanre 14).

It is important, nevertheless, that Soyinka's vision of a socially humane society did not end with the aforementioned close shave. He made other initiatives at individual level to sanitize the depraved Nigerian society. In fact, he has offered himself as a candidate for the highest office in the land: presidency. This was a testimony of his commitment to individualism in the propagation of social ideals. 
Soyinka also took his 'crusade' to the road; he was very instrumental in the establishment of the Oyo State Road Safety Corps during the tenure of Major General David Jemibewon as the military governor of Oyo State of Nigeria. The Unity Party of Nigeria civilian administration of Chief Bola Ige took over the corps in the Second Republic and reinvigorated it before it was crippled by the National Party of Nigeria's federal government. However, during the regime of General Babangida; the corps was resurrected as the Federal Road Safety Commission and the unflagging Soyinka was appointed chairman of its governing board on February 18, 1988. As a practical demonstration of his belief in commitment to social ideals and self-sacrifice, he turned down any recompense for his services as chairman.

Soyinka was also a strong voice of opposition to the government of the Western Region, which was led by Chief Ladoke Akintola in the 1960s. He objected not only to the government's institutionalization of corruption and disorder, but also to attempts by the government to perpetuate itself in power through the massive rigging of elections. In the ensuing scenario, Soyinka was accused of holding up the region's broadcasting corporation at gun point, hijacking the recorded audiocassette of the premier's speech ready for transmission, and replacing it with another carrying the message that the premier should quit office. Consequently, he was apprehended and charged, but the case could not be successfully proved against him.

It is pertinent to recognise his literary works as mines of information on the socio-political and economic ingredients that are necessary in the transformation of the Nigerian society in particular and the African continent in general. Soyinka, like many African writers, has long been engaged in theorizing identity and culture beyond monolithic paradigms that are mired in race and ethnic jaundices and so his works are rich resources for ideological and social change that has relevance to the world.

Debates about the function of literature, from which the practice of criticism can hardly be excluded, are as old as the medium itself. Issues have ranged from literature's necessary independence from politics of activism and its role in the work of social protest and change. The inexorable politics of textuality remains as pertinent an issue as the concern with the relegation of literature to politics. For the developing world, the stakes are even higher and in African societies where the reading culture remains the practice of the few, the longstanding concern with finding more innovative ways to umpire the world of the literary text to larger sections of the population is yet to be successfully addressed. The role of literature in the construction and reconstruction of a people's history cannot be overemphasised.

It would appear from the above arguments that Soyinka too uses literature as a medium for social transformation. He uses his own experiences to demonstrate the centrality of individual will social reconstruction. His return to Nigeria in the 1960s, after completing his studies at Britain's Leeds University, marked the beginning of the struggle against what he considered the forces of retrogression within the university, his primary constituency, and the larger society. He actively opposed various attempts of governments to wear down the autonomy of the university system. His two novels, and in fact most of his works, draw their raw materials from his own experiences. One notes a semblance of this struggle in The Interpreters and Season of Anomy. Indeed, The Interpreters, his maiden novel, it would appear, mirrors his own return to Nigerian shortly after independence. The short history of his social activism, which has been provided, gives a substantial ground for understanding his elevation of the individual will as the agent of social transformation.

Writing for social change is based on the longstanding tradition in Western culture of using literature as a tool for social critique, as a means of calling for social change and justice, and as a tool for social transformation. African literary works continue to serve as critical instruments for imaginatively addressing the on-going imperative for social change and self-fashioning. The work of the literary artist is to 'return the society to itself' 'to its past' and to the 'visions of the future' on which the present is constituted. Despite the fact that such a function was originally directed to a confrontation with colonialism's systemic erasure or misrepresentation of its others, an engagement that cannot be exhaustively ventilated on, post-independent African states, as is indeed captured in most literary works, have shifted their focus to the outcomes of the declaration of self-rule. This is what Wole Soyinka does in The Interpreters.

Soyinka, like other African writers, understands quite well that the continent must now engage new questions about the quality of life now available to its citizens. It has to face head on, and urgently, the many hurdles springing from all spheres of life, from its political culture, economic circumstances, gender politics and family life, marginalised 
groups, youth culture and entertainment industries, foreign interference, crime and violence. These writers do understand that it is no longer tenable to apportion blame to the past or to external forces. The apportionment of such blame terminated with the declaration of independence. Post-independent African states, African writers understand, must engage the new sites and agents of oppression or negative social conditioning generated from within and beyond its borders in order to determine the type of future that they would bestow upon their children. This is what Soyinka strives to achieve by placing the burdens of this history in the hands of a lone individual hero.

In addressing the aforementioned challenges, the question of individual will and the collective are very crucial. Soyinka deals with these two opposing mantras of social transformation in his literary works. The two novels identified are no exception. The Interpreters, to begin with, has no central plot; it is instead a sequence of dramatic scenes and lyric descriptions that follow a chronological line, interrupted by periodic flashbacks and recollections, during the rainy season in Nigeria from May through July. The action shifts from Lagos and the university city of Ibadan to the back country and lagoons outside populated areas. The main characters are university graduates, who have studied and travelled abroad and have just returned, just like the writer himself, to Nigeria because of the country's newly obtained independence.

The story revolves around the lives of Nigeria's intellectual classes. It focuses on their discourses, their interpretation of the society and their disaffection with it. The story depicts their way of living and coping with the society that they consider as backward and repugnant to change. The inception of the post-independent African leadership had offered a ray of hope for African citizens. Their ascension to power marked the dawn of a new era; however, this was not to be. The black leadership transformed into political turncoats. Young people, who had travelled overseas to acquire knowledge in order to assist in the development of their countries, have returned and what they have encountered is a chaotic political scenario analogous to the colonial era, tarzanism.

Soyinka's novel, The Interpreters, is about the petty-intellectual's detachment from the society. Soyinka uses these intellectuals, the interpreters as it were, to demonstrate that the credible agent of social transformation is the individual. The native government that has taken over from the former imperial masters is perfecting the materialist instincts of its predecessors. There seems to be little regard for spiritual values. There is, therefore, an urgent need for an individual to take over the role of evangelism from the hands of traditional evangelists who now lack the vigour and vibrancy to soldier on.

The western-educated characters in the novel that Soyinka apportions this task to comprise an artist (Kola), a writer-cum-journalist (Sagoe), an engineer and sculptor (Sekoni), a member of the elite tribal royalty (Egbo), and other peculiar characters like Golder, who is a gay theatre actor and lecturer, and Monica Faseyi who is a foreigner married to Faseyi, a very highly intransigent persona, Bandele (a professor of English) and the Oguazors. The characters in the novel are mainly intellectuals and artists who strive to make meaning out of the entirely meaningless society that they live in. As indicated earlier in this thesis, the novel draws its raw materials from the time of Nigerian independence. The intellectuals are part of the middle-class Nigerian elite, hence their experiences are removed from the upper class that controls the nation, and from the working classes that they believe form the ignoramuses. Their criticisms and rationalizations of society give them the role of interpreters, a class in itself which is divorced from the lower classes. This class is, however, entirely powerless against the upper classes. The novel patently draws its title from the role of the characters: interpretation.

In The Interpreters, Soyinka presents intellectuals who have distinct individual experiences that lead them to have a consciousness that estranges them from both the upper and lower classes. In the cases of Sagoe and Egbo, for instance, who are both educated in the west, and are both members of the middle-class bourgeoisie, foreign education has given them experiences that are highly detached and distinct from the Nigerian masses. They underestimate the masses on account of their ignorance. The interpreters also feel detached from the ruling classes which they perceive as a self-centred and very highly reactionary lot.

This portraiture is symbolic of the middle-class, post-colonial elite whose consciousness is highly disjointed given that the elite are distinctly divorced from the working-class as a whole. Conversely, it is without its own powerbase. Its dependence on foreign capital, investments and the ruling classes is quite lucid. As the elite have no position to mount a campaign of hegemony, it does not feel any linkage to the working class in the classic sense, especially the sense projected in Mao's division of classes, in which one sees the bourgeoisie linking itself, as a matter of necessity, to the working class as it strives to wield hegemony through condensing its ideology. 
The first character that demonstrates the strength of individual will is Egbo. In a flashback, a style that Soyinka explores extensively to show the relevance of the past in the construction of future ideals, Egbo's divided loyalties between the past and the present is emphasised. The only sustaining succour for the character is his 'roots.' The character craves for his past to go deep down the earth to draw the much needed 'sustaining draughts' which can only be gotten pure, clean and unpolluted when the 'roots' goes deeper into the ground to avoid distraction that could cause the roots to seek for temporary supply of water which has been contaminated, because such contamination arises when 'surface tunnels end in blinds that choke on silt and stagnate in human curses. Egbo's request for his 'roots' to get deeper into the ground evokes imagery of roots and water. The past typifies a muse which the character reaches out to, to gain inner strength and alertness as to provide the much-needed knowledge to steer the country to the path of social reorientation. The signification of past is expressed in continuous flow of words and symbols striking in their sound and message by the writer to emphasize his state of depravity, and to seek emotional fortitude to confront the seeming temptation and vulnerability which could make him compromise his stand against injustice. This is the experience that Soyinka captures in 'O Roots.' In this poem, the persona, like Egbo, makes a supplicating plea for the reinvigoration of strength and vigour to maintain his physical and mental stability to be able to confront the challenges of modernity.

Perhaps, the best example in the novel is Egbo's case. In an absurd world, in which there are no ready-made values or social codes, humans create standard sets of conduct to give meaning to the meaningless, and to create order in a chaotically absurd situation. In the novel, there is a clash between Egbo's tribal upbringing and his early colonial education, and his college education in England. On account of his education in a missionary school during his early years; he encounters admonition and physical assault from his tribal family because of his disregard for tribal traditions and codes of conduct. He is accorded the same depressing treatment from school officials, because of his primitive beliefs which he brings with him to school. The complexity of these contradictions reflects the complexity in the quest for social transformation.

It is the clash of values in Egbo's social life that represents more aptly the writer's take on social transformation. While there seems to be an obsession with the past, just like it is witnessed in Season of Anomy, strong indications are provided to show the writer's social vision. The fact that these characters have acquired western education is not coincidental; they represent Soyinka himself. Evidently, the writer's social vision that is projected in the novel, just like in Season of Anomy, lies in the immortalisation of human values. While traditional mores form an important point of reference, they cannot fully withstand the test of modernity. To understand the evolving nature of human values, an individual must be ready to delve deeper into the turbulence of water. Perhaps Egbo's recollection of his childhood reveals this more accurately:

That was a phase of course, but I truly yearned for the dark. I loved life to be still, mysterious. I took my books down there to read, during the holidays. But later, I began to go further, down towards the old suspension bridge where the water ran freely, over rocks and white sand. And there was sunshine. There was depth also in that turbulence, at least I felt down into darkness from an unfettered sky. It was so different from the grove where depth swamped me; at the bridge it was elusive, you had to pierce it, arrowed like a bird (Interpreters 9).

The burden of evangelism now lies with Egbo. The narrator says: 'And his mother was the princess Egbo whose burden it was he now carried; hers was the line of inheritance and she had gone down at the same spot and there was nothing but the rusting cannon left of her.' Egbo's role is well cut out and he understands that 'there is a blind man and a people, waiting on some mythical omniscience of [his] generation.' This is why the task of disseminating the 'Word' automatically rests with the young generation.

It must also be understood that 'the carrier' of communal aspirations, goals and values and who usually bears the burdens of history is instinctively recognised by the custodians of the traditional values. This explains how Egbo, just like Ofeyi is identified by Pa Ahime, is enthroned by his mother. The instinctive vision of Soyinka's custodians is so profound that they would not allow such wealth of knowledge to fall into dangerous hands. This sensitivity is also captured in the character of the two old women, Iya Mate and Iya Agba, in Madmen and Specialists demonstrates the power of instinct. The two have knowledge of herbs and medicines and other mysteries which together embody a cultural memory that spans back to the distant past, but they invidiously guard it from mendicants who cut the figure of degraded victims of terrorist state, and from Bero, the medical practitioner who has transformed into a 'specialist in assassination and torture. Bero, in this sense, is the state's prime agent of terror. Since the women cannot find a dependable 'carrier' who worthy of their secret and trust, 
they burn the house where they store the herbs. By doing this, they emblematically destroy the knowledge rather than allowing it into the dangerous hands of Bero and his ilk. Here the degeneration of the community is demonstrated by the old women's inability to identify one who can be trusted not to abuse the power of the knowledge deeply buried in the cultural psyche.

The communal aspirations and energies for the revolutionary transformation of the patterns of social and cultural production are bestowed on the will of the embroidered hero. The promethean hero has to be willing to sacrifice their lives to discover the true meaning of life. Egbo's village is one of the smallest creek towns but it is the richest. The government exploits, just like it does in Aiyero, to obtain material gains. To avert the possibility of a 'crack', something that penetrates nearly all the neighbouring towns, there is need for leadership. Egbo's grandfather is now tired and cannot stop infiltration. Government jobs, the Civil Service, cannot offer one an opportunity to discover the true meaning of human existence. The new African leadership preys on subservience; the moment one decides to take up a civil service job, they 'acquiesce in the system, exist in it and lend pith to hollow reeds.' Allying with the 'new gods' is antithetical to the forces of progression. To be 'released from the creek surface', one has to devote their lives to apostasy. There is need for a change in conviction and, in this new state of belief, one needs to lives spiritually not primarily in the content of that faith, in the pursuit of goals appropriate to it, but only in the struggle against the old faith and for the sake of its negation.

The clash between value systems continue up to Egbo's more mature years, where his western education and his new code of conduct, clashes with his tribal upbringing which offers him a tribal government post, and his 'enlightenment' which leads him to challenge the norms and the protocols set by the upper middle-class community. Because of invented value systems, any acting out of desire might disrupt society. The invention of values and taboos causes the alienation of a thinking individual, and forbids the acting out of desire.

In the safety and sense of Bandele's house, Egbo nearly comes to an understanding of the necessity of his pilgrimage. Though he is still afraid of what his destiny holds for him, he cannot settle until he unravels it. The unveiling of this fate personifies the quest for social transformation. He understands 'his own overwhelming need to retain that link with some out-of-the-rut existence ... illicit pleasure at the thought that a kingdom awaited him, a kingdom through its daughter whose face he could not recapture' (Interpreters 120). Although the past seems to hold him at ransom, 'this was not now a question of conscience but the progress of wisdom... All choice must come from within him, not from the promptings of the past.'

Besides Egbo, Sagoe also symbolises the post-independent intellectual elite, who feel no links on the surface, friendly or antagonistic, with the working-class. Hence, there is a sense of autonomy, and individualism, even a sense that this class does not perceive itself as a class. Aside from the groups alienation from the lower classes the group of intellectuals are also separated from, alienated and even powerless against the ruling upper-classes. Instances are frequently seen in the novel in which Sagoe uses his witty criticisms against his bosses in the press and the upper-classes. However, Sagoe still sticks to his philosophy of 'Voidancy', in which he strongly believes in being critical yet passive. Or, the case of Sekoni in which the engineer's brilliant ideas were rejected and denied, in which, even as hard as he tried to plead to the officials to consider his plans, he was still neglected and the engineer was powerless against them.

Similar sentiments are expressed in Swados' 'The Myth of a Happy Worker', which is one of the essays in Man Alone. Harvey Swados writes about how the white collar worker becomes alienated. According to him like the blue-collar worker, who is separated from the materials he works on (raw materials), and from the products that he creates but cannot own; so does the white collar worker and the bourgeoisie who, as they climb the bureaucratic structure becomes alienated from the materials they control and manipulate (the workers, who are under them), and are also dehumanized because they are also under the control and manipulated by the system (Man Alone 107113). This can be seen in the novel in Sagoe's relationship with the janitor (Mathias), whom he befriends and gives lectures on 'Voidancy.' Despite the fact that they are together, there is still a fence that separates him from the janitor.

There is still another significant factor that estranges their group from the other classes. Based on Marx's dialectics, different experiences and different consciousness lead to individual autonomy which causes estrangement from the other classes and alienation even to their own group. On account of this alienation, fragmentation and detachment from each other; the intellectual class does not even view itself as a class. In the 
novel, there is, in every character, a symbolism of an 'expert' elite, a specialist elite and there is also in the character of Kola, an artist's view and artistic activity as specialist which believes itself to be a force of clarity and truth. The masses, contrariwise, are portrayed as blind and lacking in bearing and the upper-classes are merely reactionary.

All historical progress, said Marx, results from a human desire to keep things as they are. He then proceeded to resolve this seeming contradiction. People come together, establish communities and employ given modes of production. In line with this, historical progress is a result of humans working together to fight oppression in a given historical event, and what leads to this is their similar experiences which lead them to a class consciousness, that ignites them to preserve their interests. This is the point of departure that makes Soyinka's works inconceivable, for some critics, in the context of Marxist tenets. According to Soyinka, it is individual consciousness and not class consciousness that engenders revolt against an unpleasant situation.

IThe conversation between Mathias and Sagoe delves further into the nature of social transformation that is envisaged in the novel. Sagoe calls a transition from homoeopathic Marxism to existentialism, the theory that human beings are free and responsible for their own actions in a world without meaning or God. Though the explanation provided for existentialism sounds restrictive, it does confirm the writer's leaning towards individualism, the recognition of an individual's free will as the credible step towards social transformation. To demonstrate this realisation as the most significant step towards the discovery of universal human values, he says: 'If I am personal, it is because in giving the history of myself, I do neither more or less than uncover the mystery of my philosophical development, for this is one Ritualism for which I am indebted to no predecessor but the entire world of humanity, this is one vision for which I acknowledge no Cause but the immutable laws of Nature. If I am personal, it is because this must rank as the most inward philosophy in human existence' (Interpreters 71).

Evidently, and critically so, the above declaration sounds like Soyinka's social manifesto. And indeed, like it is captured in The Man Died, one might be tempted, and quite rightly so, to equate these philosophical musings to an authorial voice. The author's own vision intrudes into the mind of Sagoe. The search that the interpreters embark on in this novel is aimed at identifying values that are 'immutable' and applicable to the 'entire world of humanity.' Here too, there is a deliberate effort to justify non-revolution as a form of revolution. 'Voidancy is not a movement of protest, but it revolts; it is non-revolutionary but it revolts. ... Voidancy is the last uncharted mine of creative energies, in its paradox lies the kernel of creative liturgy - in release is birth.'

The strength of an individual's character lies in the recognition of 'Voidant introversion' as the true meaning of human existence. Though Sagoe denies Messianic attachment to this call, he acknowledges the striking parallelism when he muses: 'I cannot help but feel that I was born to fulfil this role, for in the congenital nature of my ailment lay the first imitations of my martyrdom and inevitable apotheosis.' Acknowledgement of self sacrifice as a major component of social transformation is the only way through which one would experience, to put it in Sagoe's own words, a sense of 'self-communion, a resolution, acceptance, peace attainment' and evolve 'a spiritual rapprochement with a world of stresses and discord' (72).

Like Kola's capability to resist Golder's 'uncircumcised nakedness' (Interpreters 219), the ability of Sagoe to stand above the social corruption, which is associated with the organs of the Independent Viewpoint, an organisation whose workers are collectively lumped, it must be noted, is put to test. Soyinka approaches this through well-chosen illustrative images. Like Armah, Soyinka employs a cinematographic technique, following his spotlight over well-chosen areas and dwells on them long enough to create concrete impressions through which the moral state of the society is revealed. Through Sagoe, the writer takes the reader on a guided tour illuminating the way in which the employees of Independent Viewpoint live, the filth and squalor of the environment. The matter-of-fact way in which Soyinka builds his tenacious picture of filth and physical corruption corresponds quite accurately to Armah's The Beautyful Ones Are Not Yet Born. The preliminary description accorded to the local of the Independent Viewpoint does not escape the writer's satire:

... Sagoe, awaiting the arrival of the full complement of the Board of Interview, made his first tour of the premises. The area had been chosen, according to Mathias, for reason of pure political strategy. Every loud city has its slums, and Isale-Eko symbolised the victory of the modern African capital over European nations in this one aspect of civilisation. A few foreigners seeking off-beat local colour found it always in Isale-Eko; daring its dark maze they admitted that the experience was unique, there was hop-scotch to be played among garbage heaps, and 
the faint-hearted found their retreat cut off by the slop from housewives' basins. Independent Viewpoint owned a large building in the slum; the paper itself was a party organ, its location meant easy patronage of local thugs, and Isale-Eko was rich spawning ground.

The description of the state of the building in the slum stretches beyond this preamble. Mathias confesses that no 'local brickler' has refurbished the building and the walls are rotten to the ground. Looking through the rear window, Sagoe confirms this: 'The wall dropped sheer onto a canal which led water into the lagoon. This water was stagnant, clogged, and huge turds floated in decomposing rings, bobbing against the wall.' Ironically, when Sagoe asks Mathias how people work 'in this stench', he humorously responds that employees of the party organ say that on their first day and get used to the filth with time. Suggested here is the fact that those who do not have the individual will to resist 'the stench' are acculturated into the group's corruptible dealings.

Images of filth and stench define the surrounding of the Independent Viewpoint's building in the slum. The canteen next to the office is not spared of this morbid description of putrefaction. Sagoe orders for a drink but he cannot take it. The depth of the rot in the slum spans beyond human comprehension. The images invite not only revulsion but unmistakable disgust from the reader. The description of the quality of service and the girl who attends to the staff draws equal amount of detestation:

The two halves of the cup were held together by accumulated filth in deep crack. And it was difficult to tell what gave the special quality to the smell in the canteen, there was the greasy water in which yesterday's lunch-plates were soaked, or it could be the sweaty girl who served the staff in a stupor, a mere eighteen at the most, and her movements suggested a knee-deep wadding of sanitary towels. And she remained clogged all twenty-eight days of her cycle. Eyelids gelled to - it would appear - her navel, her only extraneous movement was to wipe her forehead with an arm that revealed an armpit in alternate streaks of black and white, powder and grime. Her whitened face further confirmed a daily toilet of powder, never water (73).

Like the Cartel in Season of Anomy, collective thoughts breed stagnation. Groups cannot be trusted with the progress of the society; they lack the moral capacity to steer the society to new frontiers. The Independent Viewpoint, which is emblematic of the Nigerian government after independence, has nothing to show as fruits of independence save for morally depraved employees like the canteen attendant who evokes the 'same squelch as her piano-key armpits.' Perhaps it is strategically stationed as an 'outer world superstructure' aimed at keeping the underprivileged in check. Indeed Mathias observes that its location is chosen on the basis of 'pure political strategy.' Chief Winsala, whose office bears all the features of a cargo worshipper, is the perfect paragon of the post-independent African leaders who are hell-bent on recruiting the masses into their collective superstructure of deception. To vindicate oneself from this cycle of chicanery, an individual has to choose 'wilfully, damn out their natural suspicion and uneasiness' (134) and embark on the search for the true meaning of life, the dome of continuity as it were. To keep quiet in the face of such social injustices amounts the death of the man in us: 'The man dies in all who keep silent in the face of tyranny' (The Man Died 13). This is the proposition at the heart of Soyinka's text.

In The Interpreters, unlike The Man Died where he has kind words for the Nigerian police, Soyinka portrays the institution as a collective superstructure robbery. The blatant nature with which this malaise is committed by the police force demonstrates the open nature of the sore. It equally shows sufficiently that the nation has not been purposively attended to by its owner or those charged with the duty of nursing and ensuring its permanent cure. The result has been a sore that has festered perennially and continues to invite flies to a bacchanal feast at the expense of the health and well being of the victim. This is the sore of the soul, of conscience which is fast becoming gangrenous and threatening the very life of Africa. In this political treatise, Soyinka indicts successive political leadership and their civilian protégés who have collaborated to pillage the continent of its resources while their nations bleed to death. Using his native Nigeria as a microcosm of the African continent, Soyinka berates postcolonial African political leadership as one that is lacking in vision and insight, reckless, and exhibits open disregard to the desires and expectations of their people. Giving his assessment on this sorry state of affairs in Nigeria, Soyinka observes:

To obtain a basic understanding of today's reality of Nigerian politics, one and to learn about and come to grasp with the phenomenon of the spoils of power. Both quantitatively and qualitatively, in aspects of tenacity and duration, of manipulations of interest groups and the scale of attendant corruption, which is usually understood by 
such people as patronage, the spoils of power continue to take central place in the various internal confrontations that have wracked that uneasy entity, Nigeria, since its fabrication by the British colonial power in 1914 (Open Sore 61).

Sagoe's encounter with the individualist taxi drivers reveals the state of lawlessness that his country had degenerated to as a result of craze for physical appetites by the police force. The taxi operators ironically perceive the officers as agents of extortion so that the earlier one settles a dispute with them using illegal means the better for them: 'They preferred personal settlement to stopping at the first policeman laying a charge' (Interpreters 109). The instantly servile and ingratiating manner with which the taxi driver treats Sagoe, the police impostor, satirically exposes the police force, the caretakers of the nation, to public ridicule. Collectively, they participate in robbery of the nation. 'These police sons of bitches,' as Sagoe calls them, instil fear on the common citizens to give them room for 'sleights.' When Sagoe, the police impersonator, alights from the taxi and leaves without asking for a coin; the taxi driver 'drove away with a sense of miracle. In his hand was still the crumpled fiveshilling note which he prepared to pass on in one of the many practised sleights of hand' (Interpreters 110).

In the context of The Interpreters, just like Season of Anomy and indeed Soyinka's oeuvre; the group is not only separated from experiences and consciousness, but also on how these intellectuals use their experiences to perceive history as it unfolds. The relationship of past and present between Joe Golder and Sekoni, which differs, is another perfect example. On the one hand, Sekoni believes in the unity and continuity of his 'dome of life.' It is said that Sekoni '... would not laugh at the actual moment of an event' (Interpreters 17); he only laughs later as if the experience of the moment of humour is not immediate or rather a humorous moment is not is not interpreted immediately, only later after the event. Joe Golder, on the other hand, 'has a habit of recollecting things as if they are just happening' (Interpreters 185). Memory (historical moments), is not the same for him, and perhaps is not memory at all but the complete repetition in all its senses and perceptions of a previous event. He is made to say of his habit of recollecting experience as immediate that 'it is a bad habit. When I am in company and I remember something unpleasant, I try to take flight before it assumes control of me' (Interpreters 185). He cannot distance a previous event as of the past but experiences it as contemporaneous.

Sekoni's memory works in fits and starts, and makes him out of sync and out of step with other people; he does not react or experience with others but understands and interprets through a framework that does not include immediacy and the present. Sekoni is a symbol of a force that cannot react spontaneously or react to the historical moment (colonial, or post-colonial). In view of the difference in the way these individuals experience an historical moment, they become out of touch with the masses and the other classes. Even the intellectuals themselves are isolated and do not consider themselves as a class; even in their small group there are different ways in which the memory is deployed.

Another main factor that estranges the characters in the story from the other classes is the passive following of the masses to the value system they blindly follow and which these intellectuals scoff at. A good example is the religious congregation led by Lazarus. The group is detached from the worship practice of the masses; they only observe and criticise the service and the protocols, rules and reactionary attitudes of those in the upper-class which the characters refuse to follow. Just like Jero's flock, the masses, who compose Lazarus' congregation, are victims of 'religious extortionists.' Lazarus introduces the strange world of evangelical religions so prevalent in modern Nigeria and a common theme in Soyinka's other work. The interpreters visit the church of the prophet Lazarus, who claims to have risen from the dead. Soyinka seems to use the religious service, which is fraught with theatrics, as well as the other pseudo-Christian rites and avowals, to emphasize the quest for spiritual values in the void of contemporary life. The activities of the interpreters themselves are part of the same quest.

Lazarus, like the swindling Jero, seems more preoccupied with 'the revenue brought into the church treasury' (Interpreters 173). He capitalizes on what Soyinka, in his penchant for coinage, calls 'optimistology' and rakes in money from them. The local prophets 'want publicity' to boost their businesses. Collective will, here too, is a subject of ridicule. It takes the strength of an individual's character to free one from the shackles of collective ignorance. Egbo says '.. if I find Lazarus is a fraud through and through, is it any business of mine to tell his congregation? That is a point on which even Bandele holds a strong opinion. Only some aspects truth are of any lasting significance. Suppose tomorrow Noah becomes Christ and Lazarus can prop him up successfully, whose truth requires me to tell the truth?' (Interpreters 180). To resist evil, one has to make tough choices. Such choices are borne out of understanding. 
Essentially, Eileen's initiation process is important, otherwise the 'flock' as Egbo says, 'would still believe what they want to believe.' Sagoe himself had struggled to bring down a 'Christ not so long ago' but could not manage because the most 'vicious attack' he had waged against him negated the spirit of 'optimistology.' In the end, collective ignorance had opened an avenue for economic prosperity. The self-imposed Christ sets up 'big transport business and a bakery and a big harem which [survives] two suits of seduction.' Collective decisions, even those made at the altar, cannot stand the test of time. Some of these decisions create room for massive exploitation of the ignoramuses.

Apart from Sagoe, the portrait of Sekoni equally demonstrates the power of individuality. Sekoni's disgust with present social conditions is quite evident and he demands some actions and change. This is why he intransigently pursues his breakthrough ideas even in the face of glaringly powerful opposition. Monica Faseyi's continual conflict with the absurd protocols of middle-class society life, such as the absence of gloves in the gathering, is equally noticeable.

True transformation of the society depends on the decision of an individual to develop an understanding of human values that stretch beyond the boundaries of time and location. This is why the evangelism that is recounted in the novel is that of 'Word.' The word symbolises the communal values that the 'carrier' personifies. The use of this metaphor is not unique to this novel. In fact, the focal character in The Road is an absurdly enigmatic professor who is on a symbolic quest for the Word. The 'Word' is conceived of as some form of cabalistic wisdom which is precious, powerful and associated with death and redemption (203). Sekoni's quest which is nipped in the bud, just like Professor's search and indeed Egbo's, may be regarded as a quest for the meaning of existence; or since it is a quest for the essence of death, it may be considered an attempt to seek immortality through the conquest of death itself.

The capitalisation of the word, a deviation from the norm, much like Plato's Truth with capital ' $\mathrm{T}$ ', foregrounds the universality of the spiritual values or ideals that are advanced in the novels. The comprehension of universal human values is pegged on an individual's willingness to search for the 'Word.' In Sekoni's own words, 'we must accept the universal dome' (Season 9). The Oshun grove symbolises the past and this why Sekoni tells Egbo that 'the dead are not strong enough to be ever-present in our being' because 'T-t-to make such d-d-distinctions disrupts the d-d-dome of c-c-continuity, which what life is.' Suggested in this proclamation is the progressive nature of social ideals, an argument that corresponds to the renewed form of the Aiyero ideal. Love cannot be 'still' and so are social ideals.

According to Sekoni, the bridge is the dome of religion. Here there is a strong indication that, though Soyinka holds religion in high regard, as indeed he does in his recognition of Yoruba gods like Ogun, he does not subscribe to the philosophy that human values are founded purely on religion. His vision of universal ideals is grounded in eclecticism. The search for the universal dome and its evangelism calls for individual sacrifice. Committed to the 'universal dome of continuity,' Sekoni draws from his knowledge as a qualified engineer and builds a small experimental power station in Ijioha. Determined to transform a society that hardly recognises the afflictions of ordinary citizens, he turns down the incessant attempts by the chairman of the board of electricity to impress upon him to sign for unnecessary expenditures (signing vouchers, letters and bicycle allowances). The board chairman convenes a meeting in which resolutions are made to have him locked out of the rural electrification programme. They do not need to 'employ these too-knows.' Sekoni, according to the chairman, needs a transfer because he is 'one of the keen ones' (Interpreters 27). His presence is a threat to the board's, to borrow Soyinka's words in Season of Anomy, 'superstructure of robbery' and swindling.

Here the collective will is the writer's object of satiric attack. The board chairman ridiculously asks one of the members to constitute himself into 'a one-man commission of enquiry' to probe the construction of the power station at Ijioha. The board is portrayed as a collection of thieves. To shield themselves from public scrutiny, they provide the one-man inquiry team with readymade conclusions: he is supposed to report that the power station is 'built without estimates.' The report presented to parliament reveals the board chairman's dirty scheme and he confesses that his presumed expert 'never fails' him as salivates on the epithets, 'a wasteful expenditure, highly dangerous conditions, unsuitable materials, unsafe operations' (Interpreters 28). Sekoni's brilliant project is written off and, at question time, the parliament resounds to 'the escapade of the mad engineer.' 
The board, especially its chairman, does not escape the writer's biting sarcasm. After the interdiction of the 'junk' engineer, 'the chairman - for his subsidiary company registered in the name of his two-month-old niece had been sole contractor for Project Ijioha - cleaned out a few thousands in immediate compensation and filed claims for a few thousands more.' Collectively, these individuals abet crime. They pose great threats to the economic development of the society. In this light, they are a hindrance to social transformation. This explains why 'bigger towns still worked their refrigerators by kerosene.' In their craze for material gains, they thwart Sekoni's vision of a 'plant that would bathe Ijioha maidens in neon glow... plans for a waterworks, to be constructed as soon as the power station was finished.' Parliamentarians, too, it is evident, do not elude the writer's satiric attack; they are portrayed as consumers of tramped-up investigations. They are easily duped and, as such, they end up issuing a blanket condemnation.

The Ijioha Project joins the list of unsuccessful government projects. Sekoni's second stint at this project is met with unmistakable hostility. The Village Head, the Chief, turns down Sekoni's desperate plea for a test and repetitively insists: 'They don't say it won't work. It will not only work, it will blow up and blow up the whole village with it' (Interpreters 30). By acquiescing to the deceptive antics of the board, the chief becomes a victim of the collective mindset. Soyinka derides the collective idea that the white man's knowledge is never objectionable. The men who condemn Sekoni's project are objects of public ridicule. Ironically, the Village Head exhorts him to leave before more people see him, an indication of the distrust that the writer holds for collective thought. The village ignoramuses are victims of manipulation by the corruptible arms of the government. They cannot stand up for their rights. Instead, and this is suggested quite humorously, they are declare that they have 'used oil-lamps until now. When the government is ready, they will build us a proper one' (Interpreters 31). They do not have the temerity to hold their leaders, and the government, to account.

It is the error of collective madness that kills Sekoni's brilliant dream. The second Commission of Inquiry finds him a mental asylum. In many ways, he, like Iriyise who represents the Aiyero ideal, personifies the Ijioha ideal. This is why he, like Iriyise who is condemned to a prison, is declared insane. Sagoe says 'people like [him] end up on the pyre' (98). His mental strength, however, serves as a significant point of reference for all the interpreters. Perhaps the noises that leave the world as Sagoe flees from silences best captures the centrality of Sekoni's life to his people. He, like the albino, carries the social vision of the Nigerian people: '.. his life our inspiration, his idealism our hopes, the survival of his spirit in our midst the hope for a future Nigeria, for moral irredentism and national rejuvenescence' (Interpreters 113).

It is the collective craze for physical appetite that have aggravated the festering sores of Africa as a continent. This is why there is need for a caretaker who has some sense of vision. The choice to guard the social values that define humanity must, of necessity, come from within even though again that moment of choice is inescapable. Here again, it is Sekoni who throws light to the interpreters' social vision. Finding it difficult to determine the relevance of the past in the construction of the future, the interpreters seek Sekoni's views. Confirming the eclectic nature of human values, Sekoni wittily observes that in 'the dome of the cosmos, there is complete unity of life. Life is like the godhead, the plurality of its manifestations is only an illusion. The godhead is one. So is life, or death, both are contained in the single dome of existence' (122). Not only does this argument reveal Soyinka's philosophy about the cyclic nature of life, but it also demonstrates the deified stature of Soyinka's characters. Sekoni is the idealist and spiritual inspiration within the group. Even after his death, he is recognized as a legendary hero. After his attempt as an engineer to construct an electric power station in a rural community is rejected by provincial and corrupt politicians, he goes insane, for the power station represents for him not simply a technological achievement but a harnessing of natural power through human creativity and was to give meaning to his new life in Africa. This failure haunts the other interpreters. They see his death in terms of a ritual sacrifice.

Another symbol of the elite's feelings of superiority and their detachment over the lower-classes is Kola's painting 'The Pantheon of The Gods', in which Kola depicts his intellectual friends as mythological gods, the gods which are worshipped by the uneducated. In his portraiture these gods are merely mythological, superior only because of their simulated attributes, and defenceless against man that created them and helpless against foreign influences. Kola, the painter, makes contact through his art - Ogun himself being the patron of artists - as he struggles to finish his masterpiece, a merging of contemporary personalities into the forms of the Yoruba gods. Egbo is Ogun, the god of contradictions, repeating the god's symbolic journey from the traditional world of spirits to the contemporary world of the living. The sculpture that Kola curves, The Wrestler, is a heroic elevation of a comic 
incident involving another of the interpreters, Sekoni. Kola's paintings show the elevated stature that Soyinka's accords the characters.

Finally, there is Bandele, apparently the cohesive force of the group. Generally a detached observer, quiet and pragmatic in his actions, he is a professor of English at the university and may be Soyinka's authorial voice. He calls for recognition of individual will, one that spouts in the face of other wills. The individual's creativity should not be stifled by the mere existence of other creators; therefore, one who has 'created their myth does not carelessly promote another's' (Interpreters 178). In so doing, he kills individual creativity. While the characters in the novel exist on many different levels, from the profoundly sacred to the farcical, the characters representing a hypocritical society reside in a world of satiric comedy, and Soyinka brilliantly exposes them to ridicule. Faseyi, Sir Derinola, Chief Winsala, Professor Oguazor, and Dr. Lumoye are 'petrified' brains, concerned only with façades and trivia. Through them, Soyinka attacks the materialism and utilitarianism that inhibit the interpreters from realizing their creative energies within the social fabric.

In conclusion, The Interpreters depicts the sense of the past encroaching on the present. The interpreters are Nigerian citizens who have acquired Western education and are vainly trying to strike a balance between the two worlds in their psyches, to change a society that has imitated and perpetuated the worst features of the new and the old. Although Soyinka uses particular details from his own Yoruban myth and theology, his aim, as his political pronouncements indicate, is Pan-African. In The Interpreters, encountering social codes causes Egbo, just like characters mentioned above, to feel isolated and withdrawn. Being intellectuals in the novel, from Dehinwa's letting her boyfriend to stay in her flat, to Golder's questioning of the norms, to Sekoni's non-conformity to the set objectives of his job, their non-conformity, questioning of the norms of society detaches them further from the reactionary consciousness of the people around them.

Though it touches every level of society, the novel concentrates on the social elite: those people who belong to the hypocritical majority and the few intellectuals, educated abroad but spiritually bound to Africa, who try to act, to find a place for themselves, and to interpret their situation. They include Egbo, the son of a tribal chief whose dilemma is to reconcile his obligations to the past and the present and whose conflicting sexual attractions to the sensuous Simi and a young university student provide a specific locus for his choice. Egbo's return with the other interpreters to visit his tribal home vividly depicts the power of tradition over the minds of the descendants. His private encounters with Ogun, the god of creation and destruction, puts him into spiritual contact with the natural world and is only one of many ways that the mythic impinges on the daily lives of the interpreters.

Instead of providing explicit solutions, however, the novel seems to end in paradox and mystery. There is a strange equation of disciples and thieves, of sinners and martyrs. The mystery of death and resurrection is present throughout the novel but reappears at the end with the symbolic, nightmarish drowning of Joe Golder, a black American, in a vat of black dye. Golder, who has no identity, who is black and yet an American rather than an African, obsessively defends the principle of negritude. Yet Soyinka also identifies him as a homosexual and, in the eyes of Sagoe, as a pervert. While Soyinka defends the integrity of the African tradition, he does not make it a matter of colour and rejects here as elsewhere the negritudist definition of the African. His vision of the African is one that reeks of convolution. The solution that he provides is an intellectually complicated one for he does not do in any dogmatic or straight-jacketed form. This could explain why the mediatory role of the promethean individual is necessary. He states as much in his second novel, Season of Anomy.

The Interpreters, therefore, ends as a night of severance: The disciples are separated, and the redeemer has not come. The interpreters are 'apostates,' but to what, they are not sure: the new world demands their acquiescence, the real or imagined past still has a spiritual hold on them or the inner self as the final sanction for responsible and heroic action. Bandele usually remains quiet in the face of the irreligious society that sacrifices its young to the preservation of itself, but he is the one who gives the parting ironic shot: 'I hope you all live to bury your own daughters' (Interpreters 251). This ironic twist reifies the inevitability of choice in the quest for demystification. The only implicit solution to the state of confusion engendered by the seeming divided loyalties is the recognition one's moment of choice. Egbo acknowledges this as Simi walks towards him: 'He watched her while she walked towards him, eyes ocean-clams with her peculiar sadness ... like a choice of a man drowning he was saying ... only like a choice of drowning.' Like Elesin's tragedy, this demonstrates that individuals cannot escape moment of choice as in the case of Egbo 'with the tide.' 
That individual is the credible vehicle of social transformation is unmistakable. The symbolic description of the cleansing period of the rains and high tides clearly shows that death is equated to sacrificial offering. Sekoni's death dismantles the 'dome of continuity' which holds the group together; consequently, it throws back each member of the group back to themselves and their shortcomings. Sekoni's mantle of a carrier figure is taken up by Noah. Noah's death signals a phase of self-realisation. The killing of the black ram (Interpreters 234) and Egbo's sexual encounter with the unnamed girl (Interpreters 134) are the other ritualistic sacrifices. The slaughtering of the ram, which is the last of the sacrifices in the novel, brings the group back together and gives the consolidated result of all the earlier sacrifices; it reifies the power of Sekoni's 'dome of continuity' and celebrates the victory of Kola and Egbo in finding meaningful linkages. The collective will, on the other hand, breeds filth, moral decadence and is generally a recipe for chaos.

Soyinka's second novel, Season of Anomy, although somewhat more sensational and melodramatic, follows archetypal patterns, including a heaven-like view of pre-colonial Africa, that assumes generalisations about the African continent and, at the same time, provide a point of contact with a foreign consciousness. It is this contact with the foreign consciousness that marks the defining moment of the writer's literary vision. An individual who is initiated into the path of reinvention is required to redefine the social vision for the continent and such individual must have a clear understanding of where he is coming from and social destination that would wish to direct members of society to. Thus this promethean hero experiences what Soyinka calls his moment of 'self-definition,' the moment when fetters were placed on his legs for the first time in his life and he says: 'I define myself as a being for whom chains are not, as, finally, a human being' (The Man Died 46).

Though The Interpreters precedes Season of Anomy, the latter appears more explicit in its handling of social issues. The portrait that is evident in Season of Anomy is not, however, any different from the first novel. The origins of Ofeyi's sacrifice in the novel grow out of his social concern to root out evil from the community. Ofeyi rises to the occasion not out of an appetite for martyrdom, but because he has the strength of character required in the opposition of injustice. He shelters Aiyero, the ideal village, from infiltration by outsiders. In the symbolic terms of the novel, Ofeyi, just like Eman who is chosen to carry the evils of the world down to the river where they can be cleansed, is born of 'the strong breed.' He also has been born for sacrifice, having fled from his own town, the city of Ilosa, after realising that his destiny lies in preservation of the social ideals upheld by the village of Aiyero. Yet it is in his blood to confront evil rather than to shun it. He abandons his advertising job and focuses on his new mission: the promotion of the Aiyero ideal. In so doing, he subscribes to the philosophy advanced by Soyinka in The Man Died: 'The first step towards dethronement of terror is the deflation of its hypocritical selfrighteousness' (16). He deflates the selfish egos of the cartel by flagrantly opposing their mission. He keeps the man alive in him by failing to align his will with those of the cartel. It is this defiance that crystallises into action in Season of Anomy.

The debate on celebration of an individual's exercise of free will, as has been indicated in earlier discussions, is not unique to the two novels under interrogation. This trend is built up in Soyinka's earlier works, notably his poetry, and it attains a climactic dimension in Season of Anomy. There are a number of his works that deal with this phenomenon. The image of the seeker in Soyinka's first novel, The Interpreters, is quite palpable. There are such characters as Sekoni and his obsessions with the universal 'dome of existence' in The Interpreters, the Professor's groping for the Word in The Road and Olunde in Death and the King's Horseman, who, in his desire to shelter his community from the ignominy of father's attempt to align his will with the white's man's, offers his life as a testament of his commitment to communal values. Evidently, the Word motif cuts across his two novels. But neither in The Interpreters nor in The Road is the question of individuality developed on as grand a scale or explored with so complex an interplay of allegory and myth as one finds it in Season of Anomy.

The quest theme in the later work runs on at least two levels; one is social and the other is personal. The two dimensions are interrelated for each reinforces the other. Ofeyi, the social reformer, is also the archetype of all eternal voyagers and all lone seekers. If allegory is the language of the social dimension of the quest, myth is the idiom of its personal dimension. At the social level, the quest for social transformation is related to what might be described as a moral alternative for a nation in a state of anomy. It is suggested in The Man Died that the Nigeria of the era of civil war might have been spared much bitterness and much suffering if it had given chance to the mediatory initiative of a revolutionary movement whose inspiration was ethical. The ethical qualification is crucial, for it is on such a moral absolute, Soyinka implies, that a new national solidarity which transcends ethnic and religious loyalties could be founded. Victor Banjo was, for Soyinka, a one-time hero of such a movement. 
Soyinka recollects the heroic acts of this figure in 'And What of it if Thus He Died?', 'Massacre, October '66' (Idanre 51-52), 'Conversation at Night with a Cockroach' (A Shuttle 5-13) and The Man Died.

Victor Banjo's Third Force was short-lived, but the idea behind the movement persists in Soyinka and in his character Ofeyi and indeed a number of other characters in his works. Explaining the Shage project to Zaccheus who is possessed of beauty of soul though utterly destitute of heroic aspirations, Ofeyi says: 'New projects like the Shage Dam meant that we could start with newly created working communities. New affinities, working-class kinships as opposed to the tribal. We killed the atavistic instinct once for all in new ventures like Shage.' The method advocated in Season of Anomy for the transformation of society differs from what Victor Banjo had envisaged. Banjo was compelled to rely on military operations by virtue of the nature of the emergency that existed in Nigeria at the time he emerged on the national scene. To this end, recollections of his character would, to some extent, fit the portrait of the Dentist in the story; however, it must be noted that the use of violence by the Dentist is lacking in any substantial social vision. Perhaps then one could still perceive Ofeyi's momentary change of tact later in the story as corresponding to that of Soyinka's historical hero. Ofeyi craves to carry out a non-violent revolution; one that fundamentally thrives on the 'trick of conversion,' on a subtle incursion into the territories of the human heart.

The portrait of the agricultural community of Aiyero, the symbolism of honest living, strikes Ofeyi as a social solidarity whose moral foundation is laid upon humane and spiritual values. In Aiyero rituals still function as a symbolic affirmation of man's indebtedness to the forces of nature; ceremonies of renewal are frequently enacted; familiar images of rebirth in Soyinka's iconography such as camwood, chalk, and oil feature in the invocations to the dead, and dawn remains the hour of communion with the divine. Aiyero is typical of the moral order that Ofeyi is in search of. However, the writer makes it clear that for him to succeed in this quest; he has first to master its heartbeat. Ofeyi has to develop a thorough understanding of its spirit, its fundamental nature, before he can embark on the transmission of its values to his own society.

Ofeyi, who is in charge of the Cartel's publicity, desires to defeat the Cartel by its own publicity method. He, a poetic whiz kid, employs genius to lend credence to the Fanonian thought, the reaction envisaged of a nature where a colonial situation persists. In the words of Franz Fanon:

Every native won in over, every native who had taken the pledge not only marks a failure for the colonial structure when he decides to lose himself and go back to his own side, but also stands as a symbol for the uselessness and the shallowness of all the work that has been accomplished. Each native who goes back over the line is a radical condemnation of the methods of the regime; and the native intellectual finds the scandal he gives rise to a justification and an encouragement to persevere in the path he has chosen (221-222).

Notably, a full comprehension of the Aiyero idea calls for an individual's ability to come to terms with those nonsexual values which Iriyise represents, for Iriyise is earth, the symbolic mother earth that had appeared in the personality of Oya in the long poem 'Idanre' (Idanre 67). In fact, like Oya, she is 'a dark sheath freed from Ogun's sword.' In one moment of insight Ofeyi acknowledges Iriyise's identity with the soil of Aiyero. 'She took to Aiyero,' he notices, 'as a new organism in search of its true element' (Season 3). Iriyise's role as the quintessence of the creative energy of earth is not lost on the people of Aiyero. The women readily identify her personality with forces that encourage growth and vegetation. 'Her fingers spliced wounded saplings with the ease of a natural healer. Her presence ... inspired the rains' (Season 20). The productivity of the land lies in her and this is why the search for her later in the story carries a symbolic significance. Her exploitation by the Cartel is emblematic of the exploitation of the nation's productive potency. Her life, her very presence, is at the heart of the community's social and economic growth. By caging her, the nation's potential for growth is stagnated.

Iriyise is linked, then, with the agricultural world of Aiyero and, by extension, with the spiritual values of that world. Evidently, there is a strong sympathy in the book between land and the moral priorities of the people that inhabit it. The spiritual values that she embodies sharply contrast the Cartel's insatiable desire for material gains. Even in Ilosa where Iriyise is pod, the exploitation of the resources of the land by the Cartel is spoken of as the 'outrage of the Pod' (Season 48). But probably more important is Iriyise's role as the personification of what Soyinka would call the spirit of revolutionary dare, the daring mental strength that forms an essential component of the fight for social realignment. In this light, she encapsulates not only the virtues of energy and motion, but also the positive forces of social change. The Dentist, who initially questions Ofeyi's stubborn search for her, later 
appraises her in this regard. This assessment is very significant in the overall understanding of the quest. He sees her as a 'touch and standard-bearer, super-mistress of universal insurgence. To abandon such political weapon in any struggle is to admit to lack of foresight. Or imagination' (Season 219).

Undeniably, the Dentist himself is also a protagonist of change. But his ethic of elimination is cast off on moral grounds even though it would appear that Soyinka himself is a master of ideological contradictions. The Dentist's obsessions with a sheer concept of violence link him with Chief Batoki or Zaki Amuri, whereas it is the point of the novel that Ofeyi's humane, almost religious approach towards social problems should be distinguished from the brutal means by which the Cartel oligarchy imposes the dictatorship of the privileged few on an unwilling many. 'When you eliminate, you have in mind something to follow,' Ofeyi tells the Dentist, 'something to replace what you eliminate. Otherwise your action is negative and futile' (Season 111). This statement seems to suggest a rationalisation of violence in the quest for social reconstruction. What Ofeyi is suggesting in this case is that the use of violence ought to be tempered with a social vision.

That Ofeyi, too, later momentarily subscribes to this ethic has been a subject of debate among many critics of Soyinka's works. As indicated elsewhere in this thesis, this momentary subscription to violence has nothing to do with Soyinka's change of attitude. Rather it is a demonstration of the promptings of the hardened part of the human soul that derails the projection of the humane domain. In fact, that Soyinka's desires a humane society is made clear in a number of instances. Humanising this society is only possible through Ofeyi; most of the events in the novel are viewed from his consciousness. His social vision does not end with the demolition of the present system. The Dentist, who might appear like his most willing compatriot, has no vision beyond the elimination of the adversary. At one point in the text, he brings this out to Ofeyi: 'Don't ask me what I envisage. Beyond the elimination of men I know to be destructively evil, I envisage nothing. What happens is up to people like you' (Season 112). Subscribing to the antics of military interregnum cannot propel a society to any progress in terms of nurturing an acceptable and enduring democratic culture unless the architect of violence subsidiarises himself to the vision of the promethean individualist, the bearer of the society's burdens of history, in this case Ofeyi. It could well be argued that the Dentist's confession brings to the fore Soyinka's regard for non-violence in individuals' efforts towards social transformation, but at the same it is implicit admission of the necessity of rationalised violence. Such are the contradictions that are at the core of Soyinka's artistry. Despite Ofeyi's numerous attempts to ignore the role of the Dentist in this mission, he implores him to 'accept the fact that [they] are still allies.' To drive his point more forcefully, he says:

You have been planting men from Aiyero all over the country. That was a deep scheme, really far-sighted but it does not interest me. I know all about that piece of anachronism. In my opinion you are all woolly-headed idealists but we can work together to destroy the Jeku. My contribution will be to lower your handicap.

The Dentist, it would appear from the above sentiments, understands just too well how significant rationalised violence can be in this quest. This is why he describes Ofeyi's incapacity to employ it as a 'handicap.' He too, just like Ofeyi who has 'imposed on [himself] a burdens to which [he lays] no claim - the self-imposed mission of stirring up a dangerous awareness in his people (the mass is his self-imposed constituency); the Dentist believes that he is utilising his acquisition, 'the art of killing', on behalf of his society. Ofeyi equally, though implicitly, appreciates the necessity of his alliance with the Dentist. The command that the Dentist exercises over his 'loyal squad of thugs' sends a 'thrill of optimism up Ofeyi's spine.' Undeniably, this partnership revivifies his energy for the quest. To cast off Ofeyi's denial, Demakin says:

I don't deny that neither my method nor yours will serve by itself. You have always taken your methods for granted, you can't envisage any means beyond converting inertia to a mass momentum. But the other side know that what they do is abnormal, it is against nature. And so they are compelled to act together, as an abnormal but organic growth. From the very start. There is one way to break such growth apart and that is to pluck off its head. Pluck it right off. They make their own rules brother. We must make ours (Season 118).

It is true that Ofeyi's first step towards the accomplishment of his goal is his dissociation with the corrupt and murderous establishment. He snaps his contacts with the Cartel but he is not without blemish. Fits of rage drive him into murderous activities and it might appear that he becomes a perpetrator of social injustice. After going through several phases of experience, it would appear, he succumbs to the employment of violence in the realisation of the ideals he had acquired from the village of Aiyero. Perhaps he uses this merely as a desperate 
measure, justified by the philosophy that desperate times call for desperate measures. He is looking for quick fixes and at this stage he finds no other effective alternative. Boahen and Falola associate Ofeyi's change of strategy to Soyinka's change of attitude. For them, 'Ofeyi's approval of violence seems to be a natural outcome of the changed attitude of Soyinka.' The substance of their arguments is presented below:

What warranted this change in Soyinka can be understood well only against the background of the social and political turmoils most faithfully relived in [Season of Anomy]. A dozen or so years of independence have reduced the Nigerian social scene to a deplorable state. The corrupt forces which drove the intellectuals to the point of despair in The Interpreters are now centred in one organisation, 'The Cartel.' Apparently The Cartel is only a cocoa plantation, but it is all powerful.

The above arguments, though wittily captured, cannot hold on a number of grounds. Soyinka has not advocated for the use of violence in his works of art. Nor has he practically vouched for it in real life. It is important to note that Soyinka has been championing for appeal to the dormant human conscience which has been dominated by the physical appetites. That the socio-political and economic state of Nigeria had degenerated into a deplorable state cannot be gainsaid; however, this is no justification for using violence to change the state of affairs. The indiscriminate use of violence has decimated millions, displaced and made them refugees in their home countries. This, no doubt, has diminished the humanity of the ordinary citizens and inflicted open sores on the people and Africa as continent, sores that have refused to heal. In any case, the Aiyero ideals that the protagonist upholds regard respect for human life, among other human rights, as a fundamental step towards social transformation. Boahen and Falola are not alone on this. Another scholar, Obi, too argues that in Season of Anomy, '[t]he problem is evident in the text's tension with respect to violence versus non-violence, on the one hand, and mass-line activism versus individual heroism on the other.'

Disregard for the sanctity of human of life is immoral and has to be condemned at all cost. Ofeyi's greatest call is that of humanisation. In fact, a close assessment of the novel reveals a well-calculated attempt to link murder with the collective mindset of the capitalists who are out to rake in material gains. The Cartel is the symbol of this collective mindset. Its operatives are so hardened that they lack the slightest of human feelings. In the writer's own words, their 'faces betray neither thought nor feeling.' They are equally 'dispassionate and indifferent to human existence.' The killing of the fugitive, and many other innocent victims, for instance, is characteristically ritualistic and reeks of perfect piousness:

As if this flicker of life was a sign, a sanction and a command that must be fulfilled before it again petered out they swept him up, bore him onto the grass verge and held him by the wasted limbs to earth. The vanished skull of one - he seemed to be the oldest among them - rose above the others and his mouth moved, shedding what seemed to be a brief devotional fragment on the scene. Then someone unsheathed a dagger, placed it in his hand. It rose, glinted briefly in the sun and the old man stooped and drew it across the throat of the prostrate figure.

His hand moved again, this time down the body, the knife-tip drew a swift, practised circle on the crotch and his other hand held up the victim's genitals. He passed it to one of the many eager hands which also uselessly opened wide to thrust out pain. Into that mouth they stuffed his penis with the testicles. Then they stepped back and looked on the transformation they had wrought (Season 164)

It is the wanton killing of innocent civilians, and particularly the incident described above, that sparks Ofeyi's outrage. The ritual outrage vividly described above is performed in the full glare of Ofe and Zaccheus. They never even care, Zaccheus says, to watch in case a car comes along: 'We were here, they never looked our way' (Season 165). The writer, however, makes it clear that his initial reaction to the killings is not motivated by his desire to transform the society and plant the Aiyero ideal. At this point in the story, his conscience, the Aiyetomic instinct so to say, is dominated by the anger.

His reaction to the Cartel's blatant disrespect for human life is one of nauseating revulsion and near mad frenzy; he cannot find rest until he avenges the fugitive's death. On account of this fervently compulsive tenacity, he repeatedly rams his car into one of the stalkers killing one on the spot. The narrator says: 'What he read on his face was a fanatic resolve to drive through again and again whenever the killers found the nerve to attempt the removal of their comrade' (Season 166). It is Zaccheus, his boon and bosom friend, who desperately crosses himself, snaps out of his passivity and appeals to his good sense and the 'sense Zaccheus made penetrated his cold, homicidal 
hate, restored him to a measure of normality.' What Soyinka is vouching for is rationalisation of violence. It should be used to heal festering sores in the society and to restore sanity; but not as a retributive action exhibited on the spur on the aggressive moment to settle temporal scores.

The Cartel is the antithesis of conscientious living. All forces of abuse and repression have amalgamated into its formation. Soyinka uses this group to demonstrate his distaste for the collective will. Their activities hardly escape the writer's satiric attack and unbridled sarcasm. It is representative of the multinational companies of the former imperialist masters in African nations. In this regard, it embodies all the characteristics that are typical of what Soyinka calls neo-tarzanists. It has a sophisticated leadership structure. It is run by a four-tier system that represents the most vital pillars of its establishment. Chief Batoki is the western governor and the brainchild behind the Cartel's operations, Zaki Amuri is the Northern traditional ruler and a lethal schemer, the commandantin-chief of the armed forces whose presence represents the support of the military in the advancement of the group's creepy activities, and Chief Biga is pseudonymically regarded as the 'Muscle Quota' of the cartel.

The Cartel does not restrict its operations to the economic exploitation of the masses. Its operatives have their egotistical interests that further overstretch the dubious activities of the group. To avert any attempts to challenge its totalitarian rule and the perpetuation of underhand activities, it uses the military stratocracy to unleash a reign of terror on individuals who oppose it. Aware that its activities do not enjoy the support of the majority, it employs the military junta to help it perpetuate its reign on the masses. It is uncomfortable with individuals who object to its activities and this is why military junta becomes handy. The propagation of the traditional but evolving Aiyero ideal poses a great threat to the stability of its establishment, especially the group's interests in the Cross-river province. In a desperate move to consolidate its power, it gives a free reign to terror in this area. Therefore, though it might superficially appear that their operations stretch beyond economic exploitation, it is evident their murderous operations are superstructural schemes meant to cement economic hegemony.

Thus his 'ardent humanism' notwithstanding, Soyinka does not admit the idea of leaving or laying the human destiny at the village square of collective will since it will lead to wars and deaths and lead to the extinction of the human species. To do so would be to deny that human community a salvation or remedy, from any of their own who is considerably privileged with a certain gift of intellectual and moral vision. The reign of the Cartel is characterized by disease and trails of destruction. The poetic quality of Soyinka's work, which is found in the satirical songs that Ofeyi composes for Zaccheus' band, exposes the bane of collective will. Given a chance, they milk the cocoa-tree (the emblem of the nation's riches), drain the nectar and peel the gold. In turn, '[t]he trees were bled prematurely old/ Nor green gold remained for the next generation' (Season 35). Putting the capital of the nation in such hands poses a serious threat to her posterity. The description of the cussedness of the Cross-river environment, 'its frequent epidemics, blindness inflicting plagues, spinal infections and mind-drugging flies' symbolizes the rot that comes with the collective will. Soyinka literally bemoans the anomy occasioned by the 'surrender of individuality' to collectivism:

Ofeyi wondered briefly, confronted by this half-human apparition, was the blood-lust that seized upon the populace just another legacy of climate? Another deformity like the effects of meningitis or the blood-poisoning of the tse-tse fly? A diminished responsibility created by a virus in the air, flooding the victims with a need to degrade more fortunate humanity in an image of their own pain and desecration? Or was there a truly metaphysic condition called evil, present in epidemic proportions that made them so open to the manipulation of the coldly unscrupulous men? There had to be a cause beyond mere differences in culture, beyond material envy - for their victims were largely equals in the court of penury, there had to be a cause beyond resentment at the right of their victims to stay different in their midst. For this was not a mere question of slaughter. A relish had coloured their actions, a deep hunger of perversion both in inventiveness and magnitude, as if they sought to balance unnatural mutations, their human forms with a vengeful outrage on the face of humanity (Season 276).

Iriyise, as has been intimated, is therefore a suitable agent of social reconstruction. Not only is her revolutionary impulse under Ofeyi's control, but she also operates through a strategy of masquerade. This strategy of disguise is perceptible in her performance in the melodramatic Pandora's Box episode or in the more subtle dance at Shage. The narrator at one point observes that Ofeyi's 'actions were one with what she symbolised' (308). Additionally, her spiritual affinities with Aiyero make her eligible to effect changes within Aiyero itself. For Ofeyi is critical of Aiyero as an esoteric hinterland. The significance of Aiyero lies in the use of its values to replace the materialistic ethos of modern cities. Its capacity to reconstruct its surrounding environment with spiritual values makes its 
presence meaningful. It is in this respect that the Asian girl Taiila is ultimately rejected as Ofeyi's companion in the quest. Emmanuel Ngara acknowledges the pivotal role that Iriyise plays in Ofeyi's quest for social reconstruction when he says:

The search for Iriyise goes beyond the search of a woman for her own sake. ... Thus for Ofeyi the search leads to a greater understanding of the dynamics of history. Even the guerrilla himself, Demakin, comes to a recognition of the necessity for relating the search for Iriyise to the revolutionary course of positively eliminating the chief exploiters of the people. His concept of the role of Iriyise is a radical and revolutionary one (103).

Taiila is the symbol of the docile will, the placid spirit of compliance. She is imagined as an 'insulated oasis of peace,' a 'still centre' that shies away from tragic encounter with 'outer chaos' (Season 238-40). She lacks the 'caged tigress' in Iriyise. She is Aiyero as Pa Ahime conceives it; her family is described as a microcosm of Aiyero (Season 238). Iriyise, on the other hand, stands for the reformed image of Aiyero which Ofeyi is endeavouring to create, that is, a more assertive, more militant and evangelical Aiyero whose values should be extended beyond its boundaries. But the docile will can be reawakened and this is exactly what Zaccheus does when Ofeyi loses it. Correspondingly, Ofeyi, after an instantaneous transformation, awakens the dormant conscience of Suberu. Twenty years of servile service as the watchdog of Temoko Prison has hardened his heart, but Ofeyi appeals to this inactive idealistic will within him. In turn, he frees himself from the collective murderous regime of the Cartel and assists Ofeyi and his group to get Iriyise out of the prison:

Can't I reach you at all Suberu? Can't I reach you in your coffin where you have been forced to lay these twenty years of your short life, responding not even to your own jangling of keys? Have we all wasted time trying to end the deadly exploitation which traps minds like yours in one lifelong indenture to emptiness? ... only you can sniff out the spot and root out the bones to accuse them. After the licks and the caresses, don't complain if the Amuris finally throw you a poisoned bone' (Season 316).

Ofeyi is just alive to the effect that Suberu's present incarceration has had on his psyche. This incarceration has drained off his strength and weakened his mental resolve. He cannot keep focus on the principle of standing on the path of truth in the face of tribulation unless this dead spirit is reawakened. Surrendering one's will to the collective whims of a murderous group like the Cartel kills one's fighting spirit.

Shage is important as Aiyero's most crucial contact with that outside world which is represented by the universe of the Cartel. The initial success of Aiyero's operations at Shage is a personal triumph for Iriyise. Her dance of the young shoot sought to re-enact the process of sowing, germination, and budding. The dance soon becomes a mystical experience, transforming her person into a blossoming shoot. Lost in its rhythmic sensation, she sprouts 'leaves and fresh buds from neck and fingers, shaking her hair free of dead leaves and earth and absorbing light and air through every pore' (Season 41). As a goddess of earth, she is capable of reactivating the re-creative energies of earth that lay dormant in Shage. The dance combines nearly the double sense of shoot as seed and idea.

The Shage earth is favourable spot, a seminal ground as it were, for the growth of the vegetational seed as well as the ideological seed. But Shage is also the scene of the Cartel's most deadly assault on forces of renewal in both the human and the natural realms. The success of the Cartel's operations of destruction at Shage plunges Ofeyi into one of his visionary moments. As he contemplates the ruins of Shage, his mind conjures up an immense chasm of nonbeing as a universal grave for desecrated humanity.

The underworld has consistently functioned as a mirror image of the actual world inhabited by doomed humanity. Such is the implication of the entombed existence of the church at the Tabernacle of Hope and of the graveyard metaphor of the mortuary episode. At Shage Ofeyi sees 'where the rest of mankind had rushed, and now his was the only consciousness observing the dark pulsating chasms of tearing, grasping, clawing, gorging humanity' (Season 176). Ofeyi's role is to heal, to infuse new life onto a flesh where the 'blood . . . had caked.' However, at Shage he seeks, albeit vainly, to invoke Ahime's scalpel of light and life on the ravines of death and waste, to inundate the chasms of nonbeing with sympathetic bleeding from the bull's elixir. After the Shage debacle, the Aiyero idea returns to its source, but the journey back marks the route, according to the Dentist, for a more determined return. 
Nonetheless, the quest for social transformation does not cease with the search for Iriyise. 'It will go on', as Ofeyi discloses (Season 242), even after Iriyise has been found. Man's eternal restlessness, Soyinka wrote, is always symbolized in an endless quest. At this point the quest theme embraces more fundamental and more personal issues. One has in mind such considerations as the artist's quest for self-knowledge, his search for beauty in its relation to art; the quest for truth in its ontological context, and, for restless individuals like Ofeyi who are forever plagued by what Taiila called his 'eternal discontent' (Season 242), the search for an emotional ballast to steady a mind in turmoil. Perhaps the question that the Dentist poses demonstrates the strength of his individual will: 'Tell me, why is it important? I mean, you've taken the most suicidal Pins over this, we know that.' Ofeyi summarily captures these other aspects of his pursuit for social reconstruction in one of his vital pearls of wit and wisdom:

But it is a little more than that. I'm sure every man feels the need to seize for himself the enormity of what is happening, of the time in which it is happening. Perhaps deep down I realise that the search would immerse me in the meaning of the event, lead me to a new understanding of history (Season 218).

From whatever angle one views the quest for social transformation; it is, by Ofeyi's understanding of it, a tragic undertaking, hence the need for mental strength on the part of the architect. In the absence of such mental strength, actualisation of social vision becomes a will-o'-the-wisp. 'Mire and mud, for some these are the paths to beauty and peace' (Season 97-98), he tells Taiila. Or consider this other confession of Taiila: 'I also seek beauty, but that kind which has been tested and stressed' (Season 99). Ofeyi, the mythic explorer, must pass through a mythic landscape, a landscape of grottos and tunnels, of stunted scrublands and hyenas, cats and vultures, which are symbolic representations of the ordeals of the questing pilgrim. Voyagers in The Interpreters traverse similar landscapes. To triumph over these impediments, Ofeyi relies increasingly on the restorative potency of rituals. He frequently evokes Ahime at moments of spiritual crisis, for he has come to associate Ahime's ceremonial scalpel with restorative essences.

Consequently, after his first major encounter with the agents of the Cartel (mainly chapter III to V), Ofeyi retreats to Aiyero's bowered sanctuary for spiritual rehabilitation. He has to retreat thither for Aiyero is a resting-place for all combatants engaged in the battles of the world. Ahime explains: 'After all the battles of the world, one needs a resting-place. And often, in between the battles. Aiyero was created for such needs' (Season 28). On this occasion, however, the restorative powers within the sanctuary speak to him of failure. The cleansing rite he performs at Labbe Bridge is more rewarding. It is important to note that the 'bridge' carries a lot of symbolic weight in Soyinka's works and The Interpreters, as one will later note in the earlier discussions in this chapter, is no exception. Nature herself participates in the ritual of cleansing. The egrets 'picked him clean of blood-infesting ticks,' and the waters 'shut his ears to all cacophony, his nostrils to pollution, transmitting only the rhythm of cropping and quiet germination' (Season 195). The water reeds evoke memories of Ahime's healing hands. They whisper healing 'incantations over a child in agony' (Season 195). Their healing vibrancies stand in sharp contrast with the death exhalations emitted by the Cartel's machinery of destruction, a stark and blatant expression of the writer's distaste for the collective gallery. Evidently, the bridge symbolises the point of transition, departure from one cultural epoch to another.

It is a feature of the novel that Aiyero should be viewed from a perspective of contrast with the universe inhabited by the agents of the Cartel. The juxtaposition of two worlds with two diversely opposed moral orders tends to resolve the tensions within the novel into an allegorical conflict between good and evil. The allegorical polarization plots the graph of the novel's symbolic structure.

The voyager Ofeyi advances from the pastoral enclaves of Aiyero to the scenes of conflict represented by Crossriver. But the allegorical demarcation has its own limitations; it imposes on the novelist's imagination certain a priori conclusions with regard to his conception of his characters. He cannot expand their human qualities to the full, since their role, and even the face of the landscape, are predetermined by the allegorical logic. Pa Ahime, for instance, is more important as a symbol than as an individual. The reader's contact with him is minimal, and rarely, if ever, is he seen in situations of psychological introspection. But it is the cripple, Aliyu, a native of Cross-river who is the best illustration of the impact on characterization of the author's allegorical imagination. Aliyu is simply an embodiment of the 'metaphysic condition called evil' (Season 276). His physical distortions reinforce the absolute deformity of mind among his Cross-river compatriots; but the use of Aliyu as an allegorical medium is ironical since he himself is not evil. 
Ofeyi is evidently Soyinka's incorruptible hero, an acknowledgement Ngugi wa Thiong'o makes in one of his sweeping statements. Valourising a Marxist literary consciousness, a position he takes in nearly all his works; Ngugi denounces Soyinka's lack of recourse to clear ideological mooring of his aesthetics in a collectivising partisanship that foregrounds and takes sides with the mass of the people and makes them the true agents and subjectivities of history. His observation, negative as it seems, summarises Soyinka's literary standpoint in Season of Anomy and The Interpreters. He felicitously opines:

Confronted with the impotency of the elite, the corruption of those steering the Ship of State, and those looking after its organs of justice, Wole Soyinka does not know where to turn. Often the characters held up for our admiration are (apart from the artists) cynics, or sheer tribal reactionaries like Baroka. The cynicism is hidden in the language (the writer seems to revel in his own linguistic mastery) and in occasional flights into metaphysics. Soyinka's good man is the uncorrupted individual: his liberal humanism leads him to admire an individual's lone act of courage, and thus often he ignores the creative struggle of the masses. The ordinary people, workers and peasants ... remain passive watchers on the shore or pitiful comedians on the road. (Homecoming 65)

Soyinka's Season of Anomy, it is evident, embraces utopian tenets that are socialist in nature. Ofeyi continues to enlighten the masses to overturn despotism. He is the ideal promethean protagonist; he combines intellect and artistry and puts creativity at the service of the community. In so doing, he does not only educate the masses, but he also learns from them. Gikandi captures this view of Soyinka's hero quite vividly:

Ofeyi is himself a developed portrait of the artistic figure in the African modernist novel: he is an interesting fusion of the pilgrim and the protagonist, a character who strives to understand his context and to change it too. His energies grow out of an idealistic desire to turn the modern wasteland into a productive garden against all the odds, and the movement of the narrative is created by the tension between his ideals and harsh historical reality. If Ofeyi does not succeed in his initial attempt to decipher the codes that make Aiyero humane, it is because of his sense of superiority; he believes he can give this community a pep talk on humanistic ideals, and what Aiyero teaches him, in turn, is to be humble. In reality, there is no antagonism between the young quester and Aiyero because both speak the same language, so that in the end the community influences the quester as much as he influences it' (Gikandi 105).

The observations made here clearly demonstrate the literary vision that Soyinka vouches for: one that recognises the role of the community in individualising the hero. The individual character who bears the burden of the community must understand his society's historical context before setting out to transform it. He draws his inspirations from his roots. The traditional mores, therefore, form an important component of the individual's initiation. Even though the responsibility of steering the community to new frontiers has been bestowed on him, he must acknowledge the efforts of his forerunners.

\section{Conclusion:-}

That Soyinka's novels cited for this study are conceived of in terms of a historical and cultural continuity is neither unusual nor surprising for he gives proof of this in his non-novelistic works, more particularly his plays and poems. It is the level that typically defined by Sekoni as 'the dome of continuity' or 'the universal dome', the dome of life where religious ideas about gods and ancestral beliefs underlying the lives of men and women of modern culture and sensibility, whose present occupations and concerns anticipate a revolutionary future. Soyinka's choice of events, incidents and development of the atmosphere is a deliberate and well-calculated attempt to achieve similar objectives in his novels. This explains his preoccupation with creeks, rivers, rocks, bridges, lagoons and gods. They supply the archetypical and mythopoeic images in the exploration of the deeper levels of his characters' minds as well as the superficial connections between the past and the present. The coexistence of these features with the man-made cities, like Ilosa, Lagos and Ibadan, and their artefacts indicates the peculiar physical basis of life. Soyinka draws his conception of life as a continuum from the African traditional world view and more particularly from the Yoruba metaphysics. Soyinka's works, as Irele puts it, hinges on 'an idea of his role as the mediator of the inner truths that sustain the collective life, and on his function in renewing the fundamental values that govern it' (192).

The mediatory role is usually accorded to a promethean hero who has a renewed sense of communal values and beliefs. In essence, Soyinka, through the revelation of cultural values and a sense of mythic consciousness, creates a novel sense of individuation whose personality drawn from the subliminal perception of a communal 
consciousness. The value of promethean role of the hero does not lie in the creation of a new society or a new moral order but in the generation of an incipient consciousness in individuals and in the futuristic destabilization thereby of the old system. The promethean individual protagonist remains a stranger and an iconoclast, dedicated to the disorientating apprehension of 'the sadness of truth' (Three Plays 105) and the demonstration of evanescent idealism. In the process he suffers victimization from the very society for whom he labours. It is The Strong Breed that perhaps encapsulates magnitude of this self sacrifice. The 'carrier' and 'cross-bearer' is humiliated (91) and immured. This is what Soyinka means when he says 'Those who have much to give fulfil themselves only in total loneliness' (94) and are therefore deeply afflicted. The description is even more vividly captured later in this play: 'Son, it is not the mouth of the boaster that says he belongs to the strong breed. It is the tongue that is red with pain and black with sorrow' (104).

\section{Conclusions:-}

Soyinka has indubitably identified himself as self-made maverick. The brief history of his political life and literary vision he advances in the two novels selected for this study corroborate this argument. Soyinka's works under investigation seem to reify integrationist philosophy, but there is even an ambitious attempt to accommodate local and metropolitan ideologies. In so doing, Soyinka portrays himself as a self-constituted project, a visionary artist and radical public academic. But it is interesting to note that Soyinka is a product of both traditional African culture and Western culture (notably, of Western Christian religion and education) as demonstrated clearly in not only his family memoirs Ake and Isara but also the novels which have formed the key subjects of this interrogation. Although he may not be a practicing Christian, biblical echoes punctuate most of his works and the two novels cited in this study are no exception. He creates messianic figures and gives in-depth treatment to the theme of willing self-sacrifice, as demonstrated in Death and King's Horseman and The Strong Breed, among others. Soyinka shuns religious dogmatism, and ridicules religious hypocrisy, as shown in his portrait of Jero in The Trial of Brother Jero and most notably Lazarus in Season of Anomy.

The discussions so far presented have demonstrated that Soyinka's exposure to Western education and culture has contributed immensely to the development of his philosophy of life, but he does not subscribe to simple oppositions like white versus black, present versus past, modernism versus tradition. Rather, he reflects different sides of these oppositions, depicting their positive and negative possibilities with a view to enabling the reader to synthesize them. With this, he reveals the complexities embedded in human life. Such a motif is apparent in two novels selected for this study. This compels the reader to judge the positive and the negative elements encapsulated in the past and the present, tradition and modernism, in order to derive a new vision enshrined in the complex pattern of seeming contradictions. The different cultures that meet in Soyinka's novels produce in human a form of cultural symbiosis such that as an objective literary scholar, critic, and activist he shuns the cutting off of any source of knowledge. It is on this principle that his universal eclecticism and a strong belief in the adaptability of human culture are anchored.

It is important to note that Soyinka's life cannot be divorced from his art and it can be said that he believes in art for the service of humanity. Indeed, Soyinka lives his art; the artist and the man in him coalesce to expose and condemn all forms of social, political, and economic ills in society. Soyinka evinces graphically his abhorrence of any form of the exploitation of individuals as well as oppression and victimization, especially at the hands of an entity of great power; this may have accounted for his being regarded as an antiestablishment figure. The brief historical background provided contains his dehumanizing and harrowing experience with the oppressive agents of government.

The two novels reveal Soyinka's celebration of individual will, the 'stray electron. 'As Soyinka demonstrates metaphorically in his poem 'Abiku,' in which he assumes the visor of an abiku, thwarting all endeavours to change his nature and make him kowtow to social pressure, Soyinka is not ready to condone any political suppression of an individual's free will. Soyinka does not align himself with people who subscribe to principles that tend to contravene the individual's will. In both novels, he bemoans the trading of human souls for material gains and this is best captured in the 'foolhardiness of this seasoned flyer who thought more of her cloth trade than the grave danger to which she thought fit to expose his life' (Interpreters 55).

In Soyinka's life, works and ideas; one, therefore witnesses a voice or life from without, a life without roots, roots interpreted to mean authority in human terms or basis. The roots or foundation of Soyinka is simply a certain claim or privilege to a social vision derived from history and the material world from where he derives and as well 
validates his claims to knowledge, wisdom and higher ideals. It is perhaps for this reason that Soyinka has been described as one who lacks faith in the collective will of the society and a 'fiercely individualistic' character. Thus his penchant for universal human values notwithstanding, Soyinka does not admit the idea of leaving or laying the human destiny at the village square of collective will since it will lead to wars and deaths and lead to the extinction of the human species. To do so would be to deny that human community a salvation or remedy, from any of their own who is considerably privileged with a certain gift of intellectual and moral vision.

This gift of vision is what Wole Soyinka claims for himself in contemporary Nigerian and the African continent. $\mathrm{He}$ attempts to substantiate and validate in his ideas and writings. It is important to note that this vision of salvation as a privileged gift which can only come from among someone in the human community runs through Soyinka's works in several themes and titles. He creates on and on a messianic personality out of several characters in his artistic works. In his work, Eman, Sekoni, Ofeyi, and Olunde, among a host of Soyinka's Christlike heroes, are ready to lay down their lives for the continuity of their race. In a section of his collection of poems Idanre titled 'Lone Figure,' Soyinka is at 'sympathy for the individual whose ideals raise him above the society he wants to save, but to which he falls a victim.' Soyinka goes further to present the irony of exceptional figures like Jesus Christ who were not seen for what they are while alive 'only to be revered after his death.' This sentiment is captured much more eloquently in the 'The Dreamer,' (Idanre 17) which is also a part of the collection, and which celebrates individuals with prophetic insight who foresees the future, what it is leading to, and how to address the challenge of the future.

Soyinka advocates for an exemplary life and his moral standard is not one that a larger class of the society may find practicable. His disposition to obvert, subvert and oppose social standards is legendary enough to merit this claim. This is the herculean task that Soyinka's intellectual and moral audiences have to grapple with. His adoption of the individualistic social formula subverts social ideals in favour of their personal ideals. One might be prompted to charge that this standpoint leads him to a cult of personality. It is then right to state of Soyinka embraces a utopian brand of artistic independence and that it is this quality that makes him stand out as a true literary maverick. It is, for instance, known that Soyinka, apart from being a literary and intellectual giant of considerable relevance, is also a hunter, who once 'spent a Christmas with animals in the bush' and contrary to any social ideal anywhere in the world, had presented a machete to a friend as wedding gift. These actions, while they may be labelled as an innovation in social and moral norms, also bespeak of Soyinka as one who is constantly in search of social and moral values and ideals almost throughout his life. It is in this context that his promethean protagonists easily fit in his unending quest for social re-orientation.

His aversion for modernity as revealed in the two novels and other works cited in this thesis also strengthen this claim of artistic independence. Thus, while he accepts modernism, and the robust quality of life it promises, Soyinka has a standing suspicion against anything unnatural, insisting that only the creative will of individual should define and determine ideals and values and that it is in this ability or rather attempt to create new realities that being human should find its meaning. Impressively however it is this effort at innovation of ideals about the human phenomenon which qualify him as a visionary and a myth maker.

In Season of Anomy, Ofeyi's on-the-spot transformation indicates that Soyinka's intellectual hero emerges from his inner sanctuary as he has the cause for fighting set before him all in solidarity. That Aiyero holds an irresistible attraction to all the basically good people is evident from the Iriyise's example. Aiyero makes a deep and profound impression on her. This fact assumes significance because up till now her 'only knowledge of fulfillment ... had been the aftermath of love.' After staying for some time in Aiyero, she declares, 'it filled me Ofe, it filled me completely where I had felt empty. I know I am now complete' (Season 7). Iriyise immediately abandons 'the circuit of Ilosa's lights, the earth of Aiyero held her deeper than any bed of eiderdown and from merely singing praises of 'cocoa complexion' she had burgeoned in unforeseeable directions' (Season 20). The cocoa-tree is representative of the country's capital which is exploited and obliterated by egocentric groups like the Cartel.

As a literary artist, Soyinka is practically rooted in his traditional Yoruba culture in spite of his attempts at realising a universal artistic outlook. He is heavily indebted to the Yoruba traditions and cultural practices for where he copiously draws the material contents of his writings. In doing so, he demonstrates, nearly overtly, the influences of his culture on his philosophy. Elements of traditional African religion permeate his works, especially the belief in pantheon of gods, goddesses, and spirits. Ogun, the god of iron, with his ambivalence of creativity and destructiveness, can be regarded as Soyinka's muse, his patron god. References to Ogun, whether explicit or implicit, are common features of his individual literary works and critical output. 
From the arguments in the preceding chapters, there is substantial evidence to prove that Soyinka's works, especially the two novels which form the basis of this research, explore the centrality of the individual in the quest for social transformation. The entire history of the African novel has been characterized by the search for an authentic identity. A home-bred sense of inadequacy and the potential risk of cultural annihilation have prompted its rise. In most cases, this comes out as a defensive mechanism and a means of cultural preservation. What the novels often lament is the loss of community, and of customs, rituals, values, and sanctions that give meaning to an individual's life. When the incursion of an alien culture began to obliterate cultural cohesiveness, alienation was an inevitable result.

Soyinka does not merely emphasise the anonymity that comes with the loss of tradition; he makes a deliberate effort to integrate the past with the contemporary world. In any case, the novel form is not only a new literary phenomenon in Africa but also a social document that traces the history of the African continent. Additionally, he demonstrates that the written tradition is now over half a century old and has gone through some form of evolution. The progressive and then the abrupt overture of the Western culture to the African tradition have created an unusual impingement, but this does not dilute his cultural vision in the novels. He recognises the existence of these opposites and the fact that they have posed a great threat to traditional African identity. In the midst of this encroachment, Soyinka advocates for what Eileen calls 'initiation', a motif stands out in most African novels.

To represent the aforesaid conflict, contradiction as it were; Soyinka nearly avoidably creates a central character that goes through an initiation experience. This technique is a significant motif in Western novels as well; however, its application appears specifically apt to the Africa novel. This is particularly true because the continent is still in its epoch of sudden transition to modernity. Even then, the society still practices such ancient initiation ceremonies as fundamental components of its communal life. In fact, according to Eileen Julien, initiation is one of three genres from the oral tradition still evident in the African novel. He advances this argument in African Novels and the Question of Orality.

In Season of Anomy and The Interpreters, Soyinka overtly vouches for non-violent revolution as a realistic and practical step towards social transformation. Such revolution can only be made possible through the ritual of initiation. Nevertheless, the process envisaged is not initiation in the naked sense of the word but a change in the character of the individual involved. The observable trend of the initiation process in Soyinka's novels is a character's introduction to Western culture, through education; a resulting split in personality and loyalties; alienation from the old community and a failure to integrate into the new one; at the extreme, a total exile from the country or a mental breakdown; and finally, in rare cases, a recovery and the beginning of efforts to reestablish ties or create a new community. This is what Ayi Kwei Armah recreates in the character of his protagonist, Baako, an individual who is trying to reestablish his ties with the community after a fractured and fragmented psyche.

Soyinka's novels strike a rare middle ground in their treatment of 'antiquity and contemporeinity.' Novels that end in alienation are likely to be realistic in mode; those novels that project a cure are likely to emphasize the archetypal aspects of the motif and rely on the romantic and mythic mode. No African novel, however, is written exclusively in one mode or the other. The novel that is perhaps the best example of the entire process is, ironically, The Interpreters, which forces a white man to discover the cultural realities of black Africa. Though traditional mores invite admiration, they cannot stand the test of objectivity; one has to be initiated anew, especially an intellectual, to reinterpret it against modern values to venerate it to a universal stature. Sartre's famous quotation comes close to the confirmation of the evolving nature of human values when he says that 'because there is no god, there is no objective standard of values....we establish and invent our values.' This is what Soyinka advocates for: reinvention.

Soyinka's novels offer rich instances of the variety that one rarely finds in the African novel that is modelled to fit into the form and content of the Western artistry. Certainly there are other archetypal motifs. Initiation itself emerges gradually into the quest, as is the case with Soyinka's Season of Anomy. The sacrificial scapegoat - in the case of Soyinka's second novel, Noah - is a common motif that arises out of the historical situation, though often the victim's death does not seem to have any immediate benefits, except perhaps in its effect within the fictional rhetoric. It is partly through the use of archetypes that the novelist, consciously or unconsciously, appeals to an international audience while reflecting local realities. The myth of paradise is a common device to contrast the old life with the new. In his novels, symbolism breaks through the realistic description. Local colour - sociological 
and anthropological documentation - is a significant part of the structure as is witnessed in the two novels selected for the study. The novelist explores the psychological impact on a highly sensitive individual reared in one culture but educated into another. The primary purpose is to show the significance of western orientation in the individual hero's initiation. The two novels are, in this regard, highly experimental, attempting to incorporate Western devices into the African context or carry over folk and mythic qualities from the past into the contemporary novel form.

Soyinka's message is that of land and labour, the capital of the nation, must be managed by members of the community - that is the Aiyero ideal that Ofeyi propagates throughout the country. A study of Soyinka's works and life will no doubt reveal undeniable consistency and harmony. He demonstrates unequivocally his basic concern for human beings, celebrating life and deprecating its opposites. Satire, sarcasm and biting wit are also outstanding characteristics of his novels. These features have earned Soyinka the tribute 'the tiger on stage.' The fact that features are equally displayed his novels earns him another accolade, 'a master storyteller.'

In summary, Soyinka has a clear literary ideology and vision as opposed to the unsubstantiated belief that he has none. In Soyinka's prose, novels in particular, just like his plays; ideology, vision and dramatic construction should, however, be understood through all the socio-political, educational, theatrical and cultural sources of influence discussed in this thesis. Superficially, one might question the relevance of dialectical materialism in critiquing the Soyinka's representation of social construction; but there is enough evidence that proves the tenability of this choice. There is a protest against an exploiting class: the political class. However, dismantling political forces, which constitute collective consciousness, cannot be achieved though the regrouping of the masses. To realise true social transformation, individuals, and not groups, should be initiated to a new faith that places premium on universal values, what Sekoni calls 'the universal dome' or 'the Aiyero ideal.' The indiscriminate use of violence, in total and flagrant disrespect for human dignity, is not the best way to realise victory over evil. But while indiscriminate use of violence and all other forms of aggression is discredited, in fact painted in the two novels discussed in this thesis as recipes for further chaos; Soyinka gives a window, narrow as might seem, for its usage so long as it is rationalised. Therefore, individual characters, which have been acculturated into the religion of new social ideals, are charged with the responsibility of evangelising, but at the same time they are allowed to use rationalised violence discriminately to achieve their social vision. Indubitably, there is usually a placid will in individuals that requires reawakening through the 'trick of conversion' but if access to such individuals is denied and violence seems like the only way to unfetter the chains that bar the individual from accessing a seminal ground for sowing seeds of social ideals then its usage becomes viable. This is demonstrated in the case of Suberu and indeed Ofeyi himself.

Whereas therefore leaving the human project open for self invention, Soyinka believes that a certain privilege of wisdom accords man the right to define truth, and to define existence for others. Thus though he does not wish that man submits his essence to social forces and authority of a collective nature, he entirely subscribes to a selfinvented authority deriving from wisdom. This wisdom is drawn from education and this is the place of intellect in social reconstruction. In his novels, one is then confronted with a profound theory of egoism; one that authorizes truth by oneself and insists that others should be ready to accept this self-invented authority. The political dimension of Soyinka's craft gestures towards a more profound creative manipulation and husbandry of cultural idioms, indigenous cosmologies and mythopoeisis peculiarly Afrocentric in the distillation of themes, construction of subjectivity, flagellation of Africa's culturality, and the refinement of an artistic vision which is at once compelling and definitive. In doing this, Soyinka's literary intent seems to be in line with Abiola Irele's conceives of modern African writing. Irele argues:

The essential direction of modern African writing, of the work of the truly significant writers, is towards the definition, in and through literature, of a definitive mode of thought and feeling, towards an imaginative apprehension and embodiment of an African spirit (Irele 45).

To investigate the practices of Soyinka as an African artist is to expose the way in which modernism has dehistorised his art, globalizing it, universalizing it, rendering it timeless and thus 'modern.' A quick rejoinder to the use of the word 'modern' in this case is that it stretches beyond the rudiments of elemental definition. In this way, modernism holds a mirror to itself, claiming for itself properties of truth and authenticity. The evolution of the African art contemplated in Soyinka's vision demonstrates a shift in museological praxis from anthropological to negotiated cultural invention. In opposition to the neutralizing of history - what his critics like Femi Osofisan 
equate to ahistorisation - and the valourisation of modernism, Wole Soyinka's novels involve the critical reader in a more interrogative instability. The synecdochal art object at the centre of the novels in question, and indeed Soyinka's works in general, represents the extreme cultural negotiation of the imperialist stage. Unlike the passive, stoic nature of Afrocentric cultural nationalism, the ritual of the artistic mask he adorns is aggressive and demanding, insisting as it does on its place in the terrifying vortex of post-colonial power politics. In his own admission in 'The Fourth Stage,' this is what he says:

The persistent search for the meaning of [artistry], for a redefinition in terms of cultural or private experience is, at the least, man's recognition of certain areas of depth-experience which are not satisfactorily explained by general aesthetic theories; and of all the subjective unease that is aroused by man's creative insights, that wrench within the human psyche which we vaguely define as [artistry] is the most insistent voice that bids us return to our own sources. There, illusively, hovers the key to the human paradox, to man's experience of being and non-being, his dubiousness as essence and matter, intimations of transience and eternity, and the harrowing drives between uniqueness and Oneness. ('The Fourth Stage', 140).

In his works, Soyinka desires to create the ethics of a 'superman.' He derives his inspiration and vision from the establishment of higher human ideal which will serve as a testament of hope in man's ability to redefine himself. Nduka Otiono, in his interview with the writer, says that Soyinka is 'an unpredictable human being whose maverick nature has seen him behaving like an apostle of oddities' (Kongi's Gunfire 47). He dissociates himself from the militant advocacy of the armed self-defense, separation from Eurocentric cultural domination and pride in and assertion of the goodness and beauty of 'blackness,' a school of thought which was propounded by Leopold Senghor and crafts a cultural philosophy that recognizes that the need for dynamism and the individual's creative potential. He sets himself apart from the advocates of Afrocentric cultural nationalism, bolekajarism as it were, and fronts a new cultural orientation that recognizes both 'the I in We' and 'the We in I.' Though he advocates for the recognition of an individual's potential in the definition of his identity, he does understand the role of 'them' in individualizing 'us.' This is the kind of humility that Aiyero demands of Ofeyi, a point that Gikandi too acknowledges, and the Creek-town demands of Egbo. As one returns to his 'sources', as Soyinka puts it, he must be ready to strike the delicate balance between 'uniqueness and oneness.'

\section{References:-}

1. Abiola, I. The African Experience in Literature and Ideology. London: Heinemann, 1981. Print.

2. Abrams, M. 'Marxist Criticism.' A Glossary of Literary Terms. Fort Worth: Harcourt Brace College Publishers, 1999. Print.

3. Aisha, K. 'Crisis of Representation in Wole Soyinka's Season of Anomy.' Marxism and Literature Revisited 24.2 (2009): 102 - 121. Print.

4. Althusser, L. and Balibar, É. Reading Capital. London: Verso, 2009. Print.

5. Arbab, F. 'The Process of Social Transformation.' The Baha'i Faith and Marxism (1987): 9-20. Print.

6. Bankole, O. WS: A Life in Full. Bookcraft, 2004. Web.

7. Biodun, J. Wole Soyinka: Politics, Poetics and Postcolonialism. Cambridge: Cambridge University Press, 2004. Print.

8. Chidi, A. 'The Ideological Content of Soyinka's Writings.' African Studies Review. 29.3, (1986): 43 - 54. Print.

9. Chidi, A. The Theory of African Literature. London: Zed Books Ltd, 1989. Print.

10. Eagleton, T. Literary Theory: An Introduction (2 ed.). University of Minnesota Press. 1996. Print.

11. Engels, F. Dialectics of nature (Translator, Clements Dutt). New York: International Publishers. 1973. Print.

12. Fischer, E and Bostock A. The Necessity of Art: A Marxist Approach. Penguin Books, 1978, Print.

13. Florence S. 'Soyinka: A Writer's Vision.' Black American Forum, 22.3 (1988) Print.

14. Franz, F. The Wretched of the Earth, Harmondsworth: Penguin, 1967. Print.

15. Gikandi, S. Reading the African Novel, Nairobi: Heinemann Kenya Limited, 1987. Print.

16. Gugelberger, G. Marxism and African Literature. Trenton, N.J.: Africa World Press, 1986. Print.

17. Julien, E. African Novels and the Question of Orality. Bloomington: Indiana University Press, 1992. Print.

18. Katrak, K. 'Theory and Social Responsibility: Soyinka's Essays.' Black American Literature Forum, Vol. 22.3 (1988) Print.

19. Lindfors, B. \& Kothandaraman, B. (Eds.) The Writer as Mythmaker: South Asian Perspectives on Wole Soyinka, USA: Africa World, 2004. Print.

20. Lynn, S. Texts and Contexts: Writing About Literature with Critical Theory. 2nd ed. NY: Longman, 1998. Print.

21. Macebuh, S. 'Poetics and the Mythic Imagination.' In Jeyifo (2001) 2001b: 27-40. Print. 
22. Mao, T. 'Talks at the Yenan Forum on Literature and the Arts,' in Selected Works, Vol. 3, Peking: Foreign Language Press, 1967. Print

23. Molara O. Recreating Ourselves - African Women and Critical Transformations. African World Press, 1994. Print.

24. Msiska, M. Postcolonial Identity in Wole Soyinka. Netherlands: Rodopi. 2007. Print.

25. Murfin, R. and Supryia M. The Bedford Glossary of Critical and Literary Terms. Boston: Bedford Books, 1997. Print.

26. Nazareth, P. Literature and Society in Modern Africa, Nairobi: PEAK, 1972. Print.

27. Nduka, O. 'Kongi's Gunfire for the Season', Preface Interview with Soyinka, Classique Magazine, Dec. 28, 1992.

28. Ngara, E. Stylistic Criticism and the African Novel. London: Heinemann Educational Books Ltd, 1982. Print.

29. . Art and Ideology in the African Novel. Nairobi: Heinemann, 1985. Print.

30. Ngugi wa Thiong'o, 'Satire in Africa.' Homecoming: Essays. London: Heinemann, 1973. Print.

31. Obi, J. 'Art, Ideology, and the Militarized African Postcolony: A Sociological Reading of Wole Soyinka's Season of Anomy.' Neohelicon 25.2 (2007): 403-415. Print.

32. Palmer, E. The Growth of the African Novel. London: Heinemann, 1979. Print.

33. Soyinka, W. Season of Anomy, London: Rex Collins Ltd, 1973. Print.

34. ㄴ. The Interpreters, London: Routledge, 1965. Print.

35. Idanre and Other Poems, London: Methuen, 1967. Print.

36. The Man Died. London: Rex Collins Ltd, 1973. Print.

37. Three Short Plays: The Strong Breed, The Trials of Brother Jero and The Swamp Dwellers. Ibadan: Oxford University Press, 1964. Print.

38. _ Isarà, A Voyage Around "Essay." New York: Random House, 1989. Print.

39. Aké: The Years of Childhood. New York: Random House, 1981. Print.

40. A Shuttle in the Crypt. New York: Hill \& Wang Publishers, 1972. Print

41. Madmen and Specialists. Oxford: OUP, 1974. Print

42. Death and the King's Horseman. New York: Norton, 1975. Print.

43. . The Open Sore of a Continent. Oxford: OUP, 1996. Print.

44. Six Plays: The Trials of Brother Jero, Jero's Metamorphosis, Camwood on the Leaves, Death and the King's Horseman, Madmen and Specialists, Opera Wonyosi. London: Methuen, 1984. Print.

45. _ 'The Writer in an African State', in Transition, 31, Kampala, June, 1967.

46. 'Neo-Tarzanism: The Poetics of Pseudo-Tradition', Transition 48, (1975): 38-44. Print.

47. Swados, H. 'Myth of the Happy Worker.' Man Alone. 107-113

48. Tayor and Francis. From Myth to Ritual: Jung Soyinka and the African World. London: Routledge 1996. Print.

49. Tejumola, O. Scars of Conquests, Masks of Resistance. Oxford: Oxford University Press, 1995. Print.

50. Ugwuanyi, L. 'I am Therefore You Are: An Existentialist Perspective on Wole Soyinka's Writings.' Unizik Journal of Arts and Humanities 12.2, (2011) Print.

51. Wiredu, K. Philosophy and an African Culture. Cambridge, U.K.: Cambridge University Press, 1980. Print.

52. Wright, D. Wole Soyinka Revisited, NY: Twayne, 1993. Print. 